\title{
Connexin-dependent intercellular stress signaling in tissue homeostasis and tumor development*
}

\author{
Jarosław Czyż ${ }^{\bowtie}$, Katarzyna Piwowarczyk, Milena Paw, Marcin Luty, Tomasz Wróbel, Jessica \\ Catapano, Zbigniew Madeja and Damian Ryszawy
}

Department of Cell Biology, Faculty of Biochemistry, Biophysics and Biotechnology, Jagiellonian University, Kraków, Poland

Cellular stress responses determine tissue development, homeostasis and pathogenesis. Paracrine signaling, exchange of mechanical stimuli and intercellular transfer of small metabolites via connexin-built gap junctional channels are involved in the cellular stress detection and propagation of stress stimuli in multicellular networks. Cellular stress responses are also regulated through the activity of unpaired connexons (hemichannels) and via the intracellular interference of connexins with the cell cycle and pro-apoptotic machinery. Therefore, connexins are considered as multidirectional transmitters of the "outside-in" and "inside-out" stress signaling that are crucial for tissue homeostasis, regeneration and pathology. In particular, the disturbance of connexin function during the multi-stage process of tumor development leads to abnormal reactions of tumor cells to stress stimuli. In this review, we outline the current knowledge on the multidirectional role of connexins in the detection of stress signals. We also discuss the role of connexinmediated intercellular transmittance of stress signals in tumour promotion, progression and metastatic cascade. Highlights:

1. Connexins and gap junctions protect cells from the microenvironmental stress and are involved in propagation and intracellular processing of stress signals.

2. The quality and quantity of stress stimuli, which may lead to cell adaptation or death by apoptosis, is determined by intrinsic properties of connexins and the cell phenotype.

3. Connexin deficiency increases the resistance of tumor cells to the "outside-in" stress signaling.

4. The connexin-mediated "inside-out" stress signaling participates in tumor cell invasion during the metastatic cascade.

Key words: carcinogenesis; connexin; gap junctions; cellular stress; tumor

Received: 18 March, 2017; revised: 19 April, 2017; accepted: 19 April, 2017; available on-line: 17 May, 2017

凶e-mail: jarek.czyz@uj.edu.pl

*The lecture that partly covered this subject had been presented during XLIV Winter School of Faculty of Biochemistry, Biophysics and Biotechnology, Jagiellonian University in Zakopane, 2017.

Abbreviations: AKT, protein kinase B; AML cells, acute myeloid leukemia cells; ATRA, all-trans retinoic acid; Bax, bcl-2-like protein 4; $\mathrm{BCl2}$, B-cell lymphoma 2; CAMP, cyclic adenosine monophosphate; CXs, connexins; EMT, epithelial-mesenchymal transition; ERK1/2, extracellular signal-regulated kinases $1 / 2$; GJIC, gap junctional intercellular coupling; GSK-3 $\beta$, glycogen synthase kinase 3 beta; HEK, human embryonic kidney cells; IP3, inositol trisphosphate; MAP, mitogen-activated protein kinase; MDR, multi-drug resistance; PI3K, phosphoinositide 3-kinase; PKC, protein kinase C; ROS, reactive oxygen species; STAT3, signal transducer and activator of transcription 3; TCDD, 2,3,7,8-tetrachlorodibenzo-p-dioxin; TNF, tumor necrosis factor; TPhT, triphenylotin; ZO-1/2, tight junction protein $1 / 2$

\section{INTRODUCTION}

Cells that reside in multicellular systems are exposed to miscellaneous stress signals. The way, a cell responds to exogenous stress stimuli is determined by their quality, amplitude and duration, as well as by a cellular long-term phenotype and momentary physiologic status. The initial response of cells to a stress stimulus aims at preserving their integrity through activation of survival pathways. However, when the noxious stimulus is unresolved, death signaling pathways that eventually eliminate damaged cells are activated. Cellular responses to stress stimuli (i.e., growth arrest, differentiation apoptosis, necrosis or autophagic cell death) depend on the "secular" ability of cells to manage stressful conditions and on their permanent phenotype (Fulda et al., 2010; Samali et al., 2010). Integrated intercellular communication networks propagate stress stimuli between cells and synchronize cellular stress reactions in tissues. They consist of membrane receptors of soluble factors, ion channels, juxtacrine receptors and gap junctional channels.

Gap junctions are semicrystalline clusters of intercellular channels, which consist of connexin family proteins (Sohl \& Willecke, 2004). Human connexins (Cxs) represent a relatively conservative family of at least 20 integral membrane proteins ranging in molecular mass between $25(\mathrm{Cx} 25)$ and $57(\mathrm{Cx} 57) \mathrm{kDa}$. Connexins include four transmembrane $\alpha$-helical domains, two intracellular termini, two extracellular and one intracellular loop. They spontaneously form hexameric hemichannels, the so-called connexons. When docking to its counterpart contributed by an adjacent cell, connexons form aqueous intercellular channels which mediate intercellular exchange of small $(<1.5 \mathrm{kDa})$ metabolites and second messengers in all the vertebrate tissues (Fig. 1; Nakagawa et al., 2010). These channels provide a route for metabolic and electrical synchronization of multicellular compartments in the process of gap junctional intercellular coupling (GJIC). Electrical coupling is crucial for synchronous excitability of tissues. In turn, metabolic coupling synchronizes cellular functions in non-excitable tissues through gap junction-mediated intercellular propagation of metabolites (Nielsen et al., 2012). The gap junction-mediated "outside-in" and "inside-out" signaling participates in the formation of local multicellular networks and governs tissue development and homeostasis in all Metazoans (Nelson \& Bissell, 2006). However, undocked connexons can also serve as membrane channels which couple the cells with their extracellular milieu (Saez et al., 2005). Finally, single connexin molecules and their fragments act as effectors of intracellular signaling pathways that regulate cell proliferation, differentiation and apoptosis (Mroue et al., 2011). 
Accumulating reports show that gap junctions confer physiologic and pathogenic stress stimuli between cells and/or mediate intercellular exchange of information on tissue constraints (Dbouk et al., 2009). Connexins also interfere with multiple pathways which regulate cell reactions to intracellular stress in the GJIC-independent manner. Cellular stress reactions are involved in developmental malformations and in chronic diseases, such as tumorogenesis (Lopez-Otin et al., 2013). In this review, we outlined the involvement of connexins in the "outside-in" and "inside-out" stress signaling between cells and their microenvironment. We also discussed the involvement of connexins in the regulation of tumor cells reactivity to stress, in particular to (i) tissue constraints and to (ii) systemic defense systems. Finally, we outlined the role of connexins in the "inside-out" stress signaling that facilitates cancer cell invasion and metastasis.

\section{THE ROLE OF CONNEXINS IN INTERCELLULAR STRESS SIGNALING}

According to the canonical view on the functions of connexins, these proteins participate in cell adaptation to microenvironmental dynamics and to tissue constraints via constituting the routes for intercellular metabolic cooperation. For example, the gap junctional channels mediate the intercellular transfer of signaling molecules, nutrients and oxygen (Berthoud \& Beyer, 2009). GJIC can locally limit cellular stress resulting from shortages of food and oxygen supply. Furthermore, gap junctions and unpaired connexons participate in the intercellular dissipation of metabolic products (e.g., $\mathrm{CO}_{2}$ and urea), reactive oxygen species (ROS) and antioxidants. Reactive products of oxygen are amongst the most potent and omnipresent threats which cells face. Import of the ROS scavengers through gap junctions can help cells to recover from the pro-oxidant:antioxidant imbalance. GJIC intensity is determined by the abundance of connexins in cell-to-cell interfaces and selectivity of channels' conductance. The composition of connexons and phosphorylation status of connexin molecules affect the quality and quantity of the transmitted molecules in a cell context-specific manner (Fig. 1; Maeda \& Tsukihara, 2011; Ek-Vitorin \& Burt, 2013; Su \& Lau, 2014). Together with GJIC-independent functions of undocked connexons and connexins localized in cytoplasm, GJIC-mediated metabolic coupling evokes tissue-specific protective responses at the cellular and tissue level. Connexin-modulated stress signaling regulates local tissue integrity and architecture (cell density and positioning, extracellular matrix properties, quality and quantity of physical cellcell interactions) through the activation/inhibition of cell proliferation/differentiation and apoptosis. Below, we outline consequences of intrinsic sensitivity of connexin molecules to stress stimuli and of connexin-mediated inter- and intracellular stress signaling for the physiology of single cells and multicellular networks.

\section{Cytoprotective connexin responses to stress stimuli}

The efficiency of GJIC depends on the availability of gap junctional channels at cell-to-cell interfaces. Therefore, connexins need to be efficiently transported from the places of their synthesis to plasma membranes to fulfill these canonical (GJIC-dependent) functions. Connexins are usually synthesized in the perinuclear zone. Upon translation, they are incorporated into the membranes of endoplasmic reticulum. Connexins localized in the cytoplasm regulate numerous intracellular signaling pathways in a GJIC-independent manner (Dbouk et al., 2009). Concomitantly, they spontaneously oligomerize into hexameric hemichannels (connexons; Laird, 2006; VanSlyke et al., 2009), undergo post-translational modifications (i.e. glicosylation and acetylation) in the Golgi apparatus and are trafficked towards plasmalemmae, where they can either reside as unpaired connexons or form intercellular channels (Fig. 1). Vesicular transport of connexins is predominantly governed by microtubules, whereas the "gap junction proteome", i.e. proteins associated with gap junctions (such as $\beta$-catenin, ZO-1 and $\mathrm{ZO}-2$, vinculin, myosins, small $\mathrm{G}$ proteins, kinases etc.), regulates the structure and functional status of the gap junctional plaques (Laird, 2006; Mroue et al., 2011). Abundance of gap junctional channels in cellular interfaces is determined by the transport of newly-synthesized connexons, the stability of gap junctional plaques and the rate of their degradation. Stress signals affect GJIC via the effect on the expression and oligomerization of connexins, their intracellular trafficking, docking of connexons and recruitment of the gap junction proteome. Actually, numerous studies demonstrated that cells can activate or attenuate connexin turn-over in response to external stress (VanSlyke \& Musil, 2005).

A relatively high rate of connexin turn-over enables cells to adapt GJIC efficiency to the dynamics of microenvironmental stress conditions (Leithe, 2016; Wong et al., 2017). Additionally, the gating of gap junctional channels is often evoked by extreme deviations in the concentrations of ions, nutrients, oxygen, metabolic products, temperature, $\mathrm{pH}$, and osmolarity of interstitial fluids (Chovatiya \& Medzhitov, 2014). When a cell dies due to the exposure to permanent starvation, the inhibition of protein glycosylation, disturbance of $\mathrm{Ca}^{2+}$ homeostasis and/or oxygen deprivation, the intrinsic mechanisms which close gap junctions are activated (for review see: Oshima, 2014). Activity of Cx40, Cx43 and Cx45 channels in cardiac tissue constitute an example of this function. These connexins built gap junctions that enable rapid transfer of $\mathrm{Ca}^{++}$waves between cardiac cells. Due to the accidental cell necrosis, intracellular $\mathrm{Ca}^{++}$concentrations typically reach pathologic (milimolar) concentrations. Gap junctional channels are closed in such conditions, thus preventing $\mathrm{Ca}^{++}$influx from dying to intact cells (Orellana et al., 2012). A similar mechanism has been described in endothelial and epithelial cells, neurons and astrocytes, fibroblasts and muscle cells (for review see: Decrock et al., 2011). Gap junctional permeability is also sensitive to pathologic changes in intracellular $\mathrm{pH}$, $\mathrm{Mg}^{2+}, \mathrm{Cl}^{-}$and $\mathrm{Na}^{+}$levels (for review see: Oshima, 2014), to the reactive oxygen species (ROS), plant toxins and to heavy metal ions. For instance, $\mathrm{H}_{2} \mathrm{O}_{2}$-induced inhibition of gap-junction intercellular communication (GJIC) in liver epithelial cells (Kim et al., 2016). The inhibitory effect of oxidative stress on GJIC was reported in neurons (Quintanilla et al., 2012), lung (Johnson \& Koval, 2009), lenses (Berthoud \& Beyer, 2009) and cardiac cells (Pogoda et al., 2016; Sovari, 2016). Moreover, administration of phorbol esters from croton oil attenuates GJIC in numerous cell types (for review see: Lampe, 1994). Cell-protective responses of gap junctions are also elicited by the challenges that are not stress signals themselves but can disrupt homeostasis (e.g. infections and allergens; Chovatiya \& Medzhitov, 2014). Consequently, the attenuation of GJIC restricts the intercellular flux of harmful compounds, whereas the quality and quantity of intercellular transfer of cytoprotective and stress molecules is determined by the selectivity of channels' conductance. 


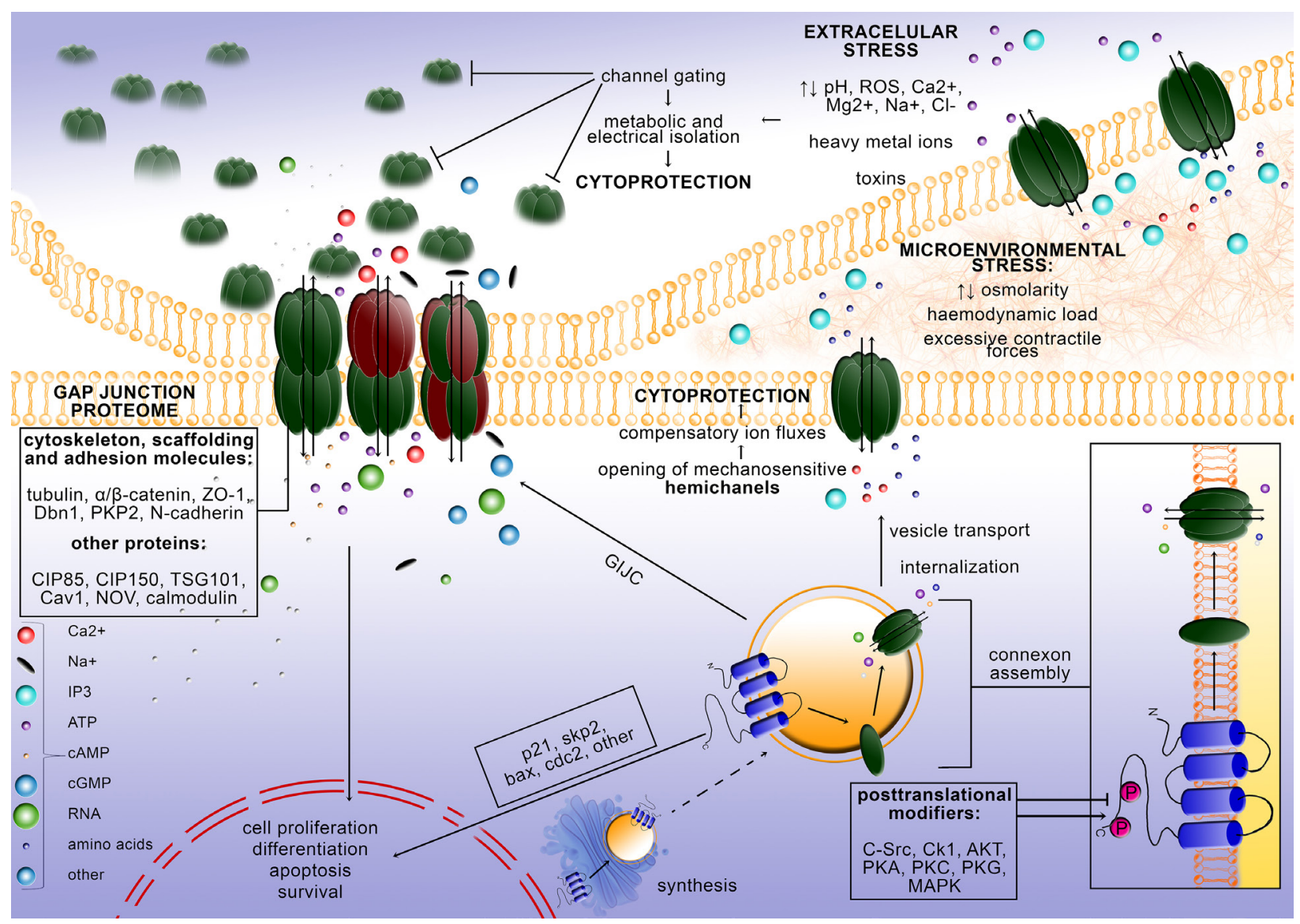

Figure 1. Gap-junction-dependent and gap-junction-independent involvement of connexins in stress signaling.

Oligomerized connexins interact with intercellular stress signaling pathways that control cell proliferation, differentiation and viability in a manner independent of gap junction-mediated intercellular coupling. When incorporated into plasmalemmae, connexons can act as paracrine conduits of intercellular stress signaling. Upon docking of two opposing connexons, an aqueous channel that enables intercellular propagation of stress stimuli is established. Compatibility of connexons and interactions of connexins with other structural and signaling molecules (i.e. the gap junction proteome) determines the channel permeability to stress signals. Abbreviations: $\mathrm{C}$, C-terminus; Cdc2, cyclin-dependent kinase 1; IP ${ }_{3}$ inositol trisphosphate; MAPK, mitogen-activated protein kinase; PKA, protein kinase A; PKC, protein kinase C; PKG, protein kinase G; skp2, S-phase kinase-associated protein 2; ZO-1, tight junction protein ZO-1.

Furthermore, unopposed connexons can fulfill cytoprotective function by facilitating cellular adaptation to hypoxia/reoxygenation, metabolic starvation and excessive mechanoosmotic stress. Connexin hemichannels mediate the rapid exchange of ions, second messengers and metabolites between the cell interior and interstitial space. They predominantly exist in a closed state under normal physiological conditions. However, it was reported that stress conditions cause the opening of hemichannels (Saez et al., 2010; Retamal et al., 2015; Pogoda et al., 2016). Increased microenvironmental osmolarity, haemodynamic load and excessive contractile forces can open mechanosensitive hemichannels and trigger compensatory ion fluxes between the cells and their milieu (De Vuyst et al., 2006; Evans et al., 2006; Saez et al., 2010; Plotkin \& Stains, 2015). In this way, the cells regulate their osmolarity, adapt cytoskeletal architecture to the vectors of excessive mechanical load and prevent the activation of pathologic cell death signalling. Collectively, sensitivity of connexin trafficking and gap junction permeability to stress signals determines the involvement of connexins in tissue and cell homeostasis. Channel gating mechanisms protect the cells from extrinsic stress via regulation of the balance between intercellular cooperation and metabolic isolation (Sohl \& Willecke, 2004;
Maeda \& Tsukihara, 2011). They participate in cell protection from toxic microenvironment, for instance from the "by-stander" propagation of cell death signals (Little, 2006). These mechanisms situate connexons and gap junctions in the category of effective and relatively universal sensors of cellular stress that isolate the cells from stressful conditions.

\section{Connexin-mediated protective cell responses}

Cellular responses to stress signals depend on their amplitude and the cell phenotype. They range from cell adaptation to necrotic or apoptotic cell death. Although channel perm-selectivity determines the quality and amplitude of stress signals received by cells, the connexin-dependent regulatory system extends beyond the rapid channel opening and closure events associated with channel gating. As already mentioned, GJIC-dependent intercellular dissipation of toxic substances, such as ROS, helps to sustain equilibrium between pro-oxidant species and antioxidant defense mechanisms such as ROS-metabolizing enzymes. This mechanism is present in lenses (Berthoud \& Beyer, 2009) and in myocardium, where sarcolemmal and mitochondrial $\mathrm{Cx} 43$ contribute to activation of a major cytoprotective PI3K in PI3KAkt-GSK-3 $\beta$ signaling in cardiomyocytes (Ishikawa et al., 2012). Finally, connexins, connexons and gap junctions 
participate in cellular perception of stress signals and in intracellular signalling responsible for cellular adaptation to stress conditions.

An illustrative example of the role of connexins in adaptative cell responses is the involvement of GJIC in regulation of cell proliferation. GJIC cooperates with chemical (paracrine) and nanomechanical stimuli during the transition of normal cells from the "activated" to "dormant" phenotype (Schalper et al., 2012). The socalled contact-inhibition of cell proliferation (Abercrombie, 1970; Castor, 1970) is commonly observed in confluent monolayers of normal cells. It is accompanied by (i) a dramatic decrease of cell motility along with the increasing cell density and by (ii) establishment of a stationary post-confluent state which is insensitive to nutrient renewal (for review see: Heckman, 2009; Puliafito et al., 2012). A picture of the mechanism that regulates these processes is still incomplete. GJIC-dependent intercellular transmission of inhibitory signals, such as cAMP and $\mathrm{Ca}^{2+}$ may account for contact inhibition of growth in crowded cell populations. For instance, it is required for endothelial quiescence in stabilized vessels. Actually, down-regulation of $\mathrm{Cx} 43$ can be sufficient to release endothelial cells from contact-inhibition of growth (Choudhary et al., 2015). Also toxic aryl hydrocarbon receptor (AhR) ligands (such as 2,3,7,8-tetrachlorodibenzo-p-dioxin; TCDD) decrease the amount of gap junction plaques, down-regulate GJIC in the AhR-dependent manner and disrupt contact-inhibition growth in liver cells (Andrysik et al., 2013). Down-regulation of $\mathrm{Cx} 43 / \mathrm{GJIC}$ may also be an inherent part of disruption of anchorage-dependence of thyroid cells (Jensen et al., 2011).

Regulation of the contact phenomena extends beyond the events associated with GJIC-dependent functions of connexins. Contact inhibition of cell proliferation may be regulated by GJIC-independent interactions of gap and adherens junctions. The recruitment of E-cadherin to cell-cell contacts and the subsequent maturation of the adherens junctions in epithelial cells (Heckman, 2009; Tinkle et al., 2008) usually inhibits cell proliferation, while their disruption can induce cell proliferation. $\mathrm{E}$ - and $\mathrm{N}$-cadherin and $\beta$-catenin are present within the gap junction proteome (Sirnes et al., 2015), where they can interact with protein kinases, ion channels and small $G$ proteins (for review see: Laird, 2006). Apparently, cadherin- and connexin-dependent sub-membranous protein complexes constitute a system (Meens et al., 2013) that integrates regulation of "social" cell behavior in tissues with the intracellular cell cycle machinery.

Moreover, numerous studies demonstrated interactions of single connexin entities with STAT3, ERK1/2 and src-dependent pathways (for review see: Vinken et al., 2011; Vinken et al., 2012). The interactions of connexins with intracellular signaling are often attributed to C-terminal of connexins and to their phosphorylation. This is well manifested in cardiomyocytes, where phosphorylation of serine 262 in Cx43 inhibits DNA synthesis independently of GJIC (Doble et al., 2004). Cx43 interferes with the function of cyclins, p27kip and S phase kinase-associated protein 2 (skp2), which regulates p27 ubiquitination in a GJIC-independent manner (Zhang et al., 2003b; Zhang et al., 2003c). Notably, these interactions inhibit logarithmic cell growth rather than participate in retardation of cell growth in confluent cultures.

Collectively, connexins take part in imposing "social" tissue constraints through suppressive "by-stander effects" mediated by GJIC. Even though the signals from neighbor cells in crowded populations do not necessarily affect cell welfare, contact-inhibition of cell proliferation can be interpreted as a pre-stress adaptation response. Multiple interceptions of connexins, connexons and gap junctions with sub-membrane assemblies of cytoskeletal and signaling molecules (i.e. gap junction proteome (Mroue et al., 2011)) and with the cell cycle machinery prevent excessive cellular crowding in tissues. They apparently create conditions for the initiation of cell differentiation and permanent reprogramming, thus participating in the maintenance of tissue integrity and functionality (Iyyathurai et al., 2016).

\section{Consequences of connexin-dependent stress signaling at the tissue level}

Whereas most insults can be overcome by the cells' natural defenses, sustained perturbations of tissue homeostasis and/or tissue rearrangements during morphogenesis or regeneration may result in the execution of pro-apoptotic programs. Whether the extrinsic and intrinsic connexin-mediated stress stimuli are interpreted by a cell as a death signal, depends on the cellular context, i.e. a phenotype of the stress-generating and stress-receiving cells. Furthermore, the amplitude, permanence and quality of stress signal, as well as the abundance, functional status and "perm-selectivity" of gap junctional channels, determines the quality and quantity of apoptotic cell responses to extrinsic stress signals.

There is ample evidence for the involvement of GJIC-mediated transfer of $\mathrm{Ca}^{2+}, \mathrm{cAMP}, \mathrm{IP}_{3}$, and reactive oxygen/nitrogen species in the programmed cell death. "By-stander" effects, i.e. gap junction-mediated intracellular propagation of stress signals induces the apoptosis in virtually all tissues (Krysko et al., 2005). The involvement of GJIC in the intercellular propagation of pro-apoptotic stimuli is illustrated by the spread of apoptotic cell death in ischemia (Contreras et al., 2004; Jeyaraman et al., 2012) and in the morphogenic processes (Krutovskikh et al., 2002). These signals can trigger the release of $\mathrm{Ca}^{2+}$ from endoplasmic reticulum. Intracellular $\mathrm{Ca}^{2+}$ contributes to the regulation of apoptotic cascades and mitochondrial permeability, thereby amplifying the intracellular pro-apoptotic signaling (Orrenius et al., 2003). Corresponding involvement of GJIC in apoptotic cell responses was observed in liver, where hepatic gap junctions play a crucial role in local propagation of antiviral immune response signaling (Knabb et al., 2007). By contrast, GJIC inhibition in hepatocytes down-regulated the activity of caspase-3, a major contributor in the proapoptotic cascades (Naiki-Ito et al., 2010). Gap junctions and hemichannels built of $\mathrm{Cx} 43$ are also involved in $\mathrm{H}_{2} \mathrm{O}_{2}$-mediated cell death in epithelial cells and osteocytes (Ramachandran et al., 2007; Hutnik et al., 2008; Kar et al., 2013). $\mathrm{Cx} 43$ modulates $\mathrm{H}_{2} \mathrm{O}_{2^{-}}$and $\mathrm{H} / \mathrm{R}$-induced cell death in astrocytes and these distinct effects of $\mathrm{Cx} 43$ correlate with differential regulation of $\mathrm{Cx} 43$ phosphorylation and spatial distribution.

Furthermore, the intracellular fraction of connexins participates in GJIC-independent intracellular amplification of pro-apoptotic signals (Kardami et al., 2007). For instance, mitochondrial connexons may confer cell fate/ death signals (Baines, 2010). Along with a panoply of mitochondrial proteins/complexes involving $\mathrm{Bcl} 2$, Bax and $\mathrm{K}(\mathrm{ATP})$ channels, $\mathrm{Cx} 43$ has been implicated in mitochondrium-related cell death. These functions can also be executed by single connexin molecules and hemichannels localized in the nucleus (Rodriguez-Sinovas et al., 2007). Finally, due to the multiple interceptions between signaling pathways that regulate cell proliferation/growth arrest, the interference of connexins with the function 
of MAP kinases, p27 and other cell cycle effectors can be translated into apoptotic cell responses (Vinken et al., 2012).

Collectively, connexin-mediated stress signaling activates cell adaptation mechanisms, which prevent abnormal tissue hyperplasia and are important for elimination of excessive or irreversibly damaged cells. These mechanisms add to the role of connexin-mediated stress signaling in tissue homeostasis, development and regeneration. Notably, "outside-in" signalling pathways can activate signaling loops that close gap junctional channels in the apoptotic cells. This mechanism represents an adaptation system that protects tissue homeostasis through metabolic isolation of apoptotic cells. Multidirectional functions of connexins in the regulation of cell proliferation and apoptosis place them in the category of multifunctional, signaling micro-domains involved in "outside-in" stress signaling that preserves tissue integrity and homeostasis (Dbouk et al., 2009).

\section{CONNEXIN-MEDIATED CELLULAR STRESS IN TUMOR DEVELOPMENT}

Tissue homeostasis, development and regeneration depend on the cooperation between connexin-dependent intra- and intercellular pathways and paracrine/mechanical signaling (Nelson \& Bissell, 2006). Accordingly, abnormal propagation and amplification of intercellular stress signaling, which disturbs cell reactivity to extrinsic stress stimuli, is the physiological outcome of connexin dysfunctions. At the tissue level, the disturbances in generation, detection and propagation of stress signals lead to numerous abnormalities, such as developmental malformations, inflammatory diseases and tumor (for review see: Wong et al., 2016; Wong et al., 2017). For instance, increased proliferation of keratinocytes in psoriasis is attributed to increased Cx26 levels (Aasen, 2015). Notably, subtle changes of connexin expression, trafficking and turnover participate in dysfunctional social behavior of the cells, leading to cell transformation. Cx32-knockout mice exhibited resistance to liver cell death induced by D-galactosamine and carbon tetrachloride (Asamoto et al., 2004), and the increased predisposition to liver cancer (Hokaiwado et al., 2007). It is conceivable that injured hepatocytes may escape apoptosis upon Cx32 removal, which poses a risk factor in carcinogenesis (Naiki-Ito et al., 2010). Indeed, associations between low expression of connexins in tumors and a poor prognosis have been reported for numerous tumors, including prostate, colorectal and breast cancer (Benko et al., 2011; Teleki et al., 2014; Sirnes et al., 2015; Grek et al., 2016). The relevance of connexin (dys)function for carcinogenesis was also supported by reports (i) on the interference of chemical carcinogens with the function of connexins in normal cells, (ii) on the postulated role of connexin deficiency in anchorage-independent and contact-resistant tumor cell proliferation, (iii) on the interrelations between connexin (dys)functions and the resistance of tumor cells to apoptosis and (iv) on the role of connexin-mediated "insideout" signaling in tumor invasion and metastasis. Below, we propose how the combination of these effects can contribute to cancer promotion and progression (Fig. 2).

\section{Connexin deficiency and cell transformation}

Occasional transmission of stress signals through gap junctions can lead to "physiologic" apoptosis that eliminates excessive or damaged cells from tissues. Therefore, the resistance of tumor cells to these signals may result from connexin dysfunction. The role of intracellular transfer of metabolites in cancer promotion was experimentally analysed for the first time in the late 1960s, i.e. long before connexins had been discovered (Loewenstein \& Kanno, 1966; Loewenstein \& Kanno, 1967). Early demonstrations of the fact that cancer cells are less communicated than their normal counterparts were underlined by a plethora of reports on connexin dysfunction in cancer cells (Laird, 2006; Leithe et al., 2006). Chemical carcinogenes, such as phorbol esters, exert an inhibitory effect on the expression and/or function of connexins in numerous cell types, incl. hepatocytes and keratinocytes (Ren et al., 1998; Langlois et al., 2010). Accordingly, it is commonly assumed that connexins, gap junctions and GJIC may stabilize a "normal" cell phenotype, whereas connexin dysfunctions participate in the resistance of tumor cells to stressful microenvironment of primary tumors.

Phorbol esters impair GJIC through the protein kinase C (PKC)-dependent phosphorylation of connexins (Chipman et al., 2003). A similar activity of lindane (hexachlorocyklohexan) in liver and myometrial cells was attributed to the oxidation of glutathione (Loch-Caruso et al., 2004; Caruso et al., 2005). We have demonstrated that triphenylotin (TPhT) closes $\mathrm{Cx} 43$ channels in human embryonic kidney (HEK) cells through ROS-dependent activation of PKC (Sroka et al., 2008). This finding confirms that $\mathrm{Cx} 43$ functions as a sensor of oxidative stress. Metabolic isolation of tumor cells is the primary outcome of connexin deficiency and dysfunction. Thus, the cells are released from the control regime of the tissue because GJIC impairment prevents intercellular propagation and intracellular amplification of stress stimuli. On the other hand, the dysfunction of connexins can also attenuate intercellular fluxes of harmful compounds from dysfunctional cells to their intact neighbors, leading to accumulation of toxic metabolites (such as ROS) in metabolically isolated cells (Tsujino et al., 2007; Vinken et al., 2012). Deficient/abnormal connexin expression, disturbance of connexin trafficking (Leithe, 2016), deregulated gating and selective permeability of gap junction channels may thus contribute to the accumulation of mutations in tumor cells' genome (incl. connexin-coding genes). Such mutations are commonly observed in the genes encoding the effectors of GSK3 $\beta$, src/PKC and cAMP-dependent cascades. Because these pathways participate in the"oncogenic transformation" and concomitantly regulate connexin expression (reviewed by: Lee et al., 1991; Chipman et al., 2003), "vicious circles" that account for heritable $\mathrm{Cx} 43, \mathrm{Cx} 32$ and $\mathrm{Cx} 26$ dysfunction in tumor cells may be constituted. Due to the possible involvement of connexin dysfunction in disturbed genetic stability of tumor cells, connexins are often claimed to represent class II suppressors.

\section{Connexin deficiency and stress-resistance of tumor cells}

Tumor cell populations in vitro and in vivo are characterized by extreme phenotypic heterogeneity, which concerns gene expression, proteome, secretome, composition and architecture of surface complex, adhesive properties, morphology, motility, contractility etc. Apparently, this heterogeneity illustrates the complexity of microevolution routes undertaken by tumor cell lineages in the dynamic microenvironment of primary tumor. In contrast, anchorage-independent growth and relative insensitivity to cellular crowding are characteristic for the vast majority of tumor cells. Even though there are several reports on cytoprotective effects of $\mathrm{Cx} 32, \mathrm{Cx} 43$ and 
Table 1. Effect of connexin manipulations on the susceptibility of tumor cells to pro-apoptotic and cytostatic signals

\begin{tabular}{|c|c|c|c|c|c|}
\hline Connexin & Tumor & Parameter & & Mechanism & References \\
\hline Cx43个 & prostate cancer & apoptosis $\uparrow$ & proliferation $\downarrow$ & n.d. & (Lu et al., 2015; Li et al., 2016) \\
\hline $\mathrm{Cx} 43 \uparrow$ & glioma & apoptosis $\downarrow$ & proliferation $\uparrow$ & GJIC-independent & (Gielen et al., 2013) \\
\hline $\mathrm{Cx} 43 \uparrow$ & glioma & apoptosis $\uparrow$ & n.d. & GJIC-independent & (Huang et al., 2001) \\
\hline $\mathrm{Cx} 43 \uparrow$ & hepatoma & apoptosis $\uparrow$ & proliferation $\downarrow$ & GJIC-dependent & (Liu et al., 2009) \\
\hline $\mathrm{Cx} 43 \uparrow$ & mammary carcinoma & apoptosis $\uparrow$ & proliferation $\uparrow$ & GJIC-dep/indep & (Shishido \& Nguyen, 2016) \\
\hline $\mathrm{Cx} 43 \uparrow$ & breast cancer & apoptosis $\uparrow$ & n.d. & GJIC-dependent & (Chang et al., 2013) \\
\hline $\mathrm{Cx} 43 \uparrow$ & medulloblastoma & apoptosis $\uparrow$ & n.d. & n.d. & (Sun et al., 2012a) \\
\hline $\mathrm{Cx} 43 \uparrow$ & mesothelioma & apoptosis $\uparrow$ & proliferation $\downarrow$ & GJC-independent & (Sato et al., 2009) \\
\hline $\mathrm{Cx} 43 \uparrow$ & nasopharyngeal tumor & apoptosis $\uparrow$ & proliferation $\downarrow$ & GJIC-independent & (Hattori et al., 2007) \\
\hline Cx43个 & melanoma & apoptosis $\uparrow$ & proliferation $\downarrow$ & GJIC-dependent & (Tittarelli et al., 2015) \\
\hline $\mathrm{Cx} 43 \uparrow$ & pancreatic cancer & apoptosis $\uparrow$ & n.d. & GJC-independent & (Sun et al., 2012b) \\
\hline$C \times 43 \downarrow$ & prostate cancer & apoptosis $\downarrow$ & proliferation $\downarrow$ & n.d. & (Li et al., 2012) \\
\hline 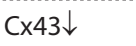 & bladder cancer & apoptosis $\uparrow$ & proliferation $\downarrow$ & n.d. & (Ai et al., 2017) \\
\hline 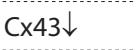 & glioma & apoptosis $\downarrow$ & proliferation $\uparrow$ & n.d. & (Jin et al., 2013) \\
\hline$C \times 43 \downarrow$ & Giant-cell tumor of the bone & apoptosis $\downarrow$ & n.d. & GJIC-dependent & (Balla et al., 2015) \\
\hline $\mathrm{C} \times 32 \uparrow$ & hepatoma & apoptosis $\uparrow$ & proliferation $\downarrow$ & n.d. & (Wu et al., 2016; Liu et al., 2009) \\
\hline $\mathrm{C} \times 32 \uparrow$ & lung adenocarcinoma cells & apoptosis $\uparrow$ & n.d. & n.d. & (Sato et al., 2007a) \\
\hline $\mathrm{C} \times 32 \uparrow$ & renal carcinoma & apoptosis $\uparrow$ & proliferation $\downarrow$ & n.d. & (Sato et al., 2007b) \\
\hline $\mathrm{C} \times 32 \uparrow$ & renal cancer & apoptosis $\uparrow$ & proliferation $\downarrow$ & GJIC-dependent & (Fujimoto et al., 2004) \\
\hline $\mathrm{C} \times 26 \uparrow$ & prostate cancer & apoptosis $\uparrow$ & proliferation $\downarrow$ & n.d. & (Tanaka \& Grossman, 2004) \\
\hline $\mathrm{C} \times 26 \uparrow$ & bladder cancer & apoptosis $\uparrow$ & proliferation $\downarrow$ & n.d. & (Tanaka \& Grossman, 2001) \\
\hline $\mathrm{C} \times 37 \uparrow$ & gastric tumor & apoptosis $\uparrow$ & n.d. & n.d. & (Jing et al., 2014) \\
\hline $\mathrm{C} \times 37 \uparrow$ & insulinoma & apoptosis $=$ & proliferation $\downarrow$ & n.d. & (Burt et al., 2008) \\
\hline$C \times 46 \downarrow$ & breast cancer & apoptosis $\uparrow$ & proliferation $\downarrow$ & n.d. & (Banerjee et al., 2010) \\
\hline$C \times 25 \downarrow$ & leukemia & apoptosis $\uparrow$ & proliferation $\downarrow$ & GJIC-dependent & (Sinyuk et al., 2015) \\
\hline Cx30个 & glioma & apoptosis $\downarrow$ & proliferation $\downarrow$ & n.d. & (Artesi et al., 2015) \\
\hline
\end{tabular}

Cx46 on cancer cells (Banerjee et al., 2010), their dysfunction generally attenuates the sensitivity of tumor cells to growth-retarding and pro-apototic signals (Table 1 ). Accordingly, misperception of the presence of neighboring cells is considered as a fundamental milestone in the development of tumors. Numerous studies showed that the ectopic $\mathrm{Cx} 26, \mathrm{Cx} 32$ and $\mathrm{Cx} 43$ expression in connexin-deficient glioma (Goldberg et al., 2000), melanoma (Su et al., 2000), breast (Hirschi et al., 1996; Momiyama et al., 2003) and prostate cancer cells (Mehta et al., 1999) leads to a partial reversion of their transformed (anchorage-independent) phenotype and to restoration of the contactinhibited growth.

The up-regulation of connexins has also been shown to increase the sensitivity of tumor cells to the pro-apoptotic stimuli (for review see: Kandouz \& Batist, 2010). For instance, $\mathrm{Cx} 43$ up-regulation induced by all-trans retinoic acid (ATRA) increased the sensitivity of prostate cancer cells to docetaxel (Nehme et al., 2001). Ectopic Cx43 expression was shown to sensitize HeLa cells to apigenin (Czyz et al., 2005). Cx43 also increases the sensitivity of prostate cancer cells to ganciclovir after adenoviral delivery of the herpes virus thymidine kinase suicide gene and to combined ganciclovir/tumor necrosis factor (TNF) therapy (Hattori \& Maitani, 2005; Wang et al., 2007). Similarly, Cx43 up-regulation increased the sensitivity of human glioblastoma cells and AML cells to etoposide, paclitaxel and doxorubicin ( $\mathrm{Li}$ et al., 2006; Foss et al., 2010). Chemosensitivity of tumor cells may also be increased by the ectopic expression of $\mathrm{Cx} 26$ and Cx32 (Foss et al., 2010). Collectively, disturbed intercellular propagation of growth inhibitory and pro-apoptotic signals, which results from connexin deficiency/dysfunction in tumor cells, supports their clonal expansion and unrestricted growth. In turn, restoration of connexin functions augments the sensitivity of tumor cells to pro-apoptotic signals (Table 1).

In addition to the GJIC-dependent connexin functions, the GJIC-independent signaling pathways regulate cytostatic and pro-apoptotic cell responses to extrinsic stress (Carette et al., 2014). Accordingly, connexin deficiency may attenuate the activity of these pathways in tumor cells, thus augmenting their resistance to stress signaling. For instance, GJIC-independent interference of C-terminal fragments of Cx43 with skp2/p21-dependent cascade is dysfunctional in tumor cells. Down-regulation of cyclin D1 was shown upon $\mathrm{Cx} 43$ transfection in E9 mouse lung carcinoma and osteosarcoma cells. This effect correlated with up-regulation of p27kip-1 (Koffler et al., 2000; Zhang et al., 2003c; Vinken et al., 2011). On the other hand, GJIC-independent involvement of $\mathrm{Cx} 26$ in the regulation gene expression was seen in breast tumor cells (Qin et al., 2003). Cytoplasmic, mitochondrial and nuclear connexins also regulate pro-apoptotic cascades in the GJIC-independent manner. They contribute to 


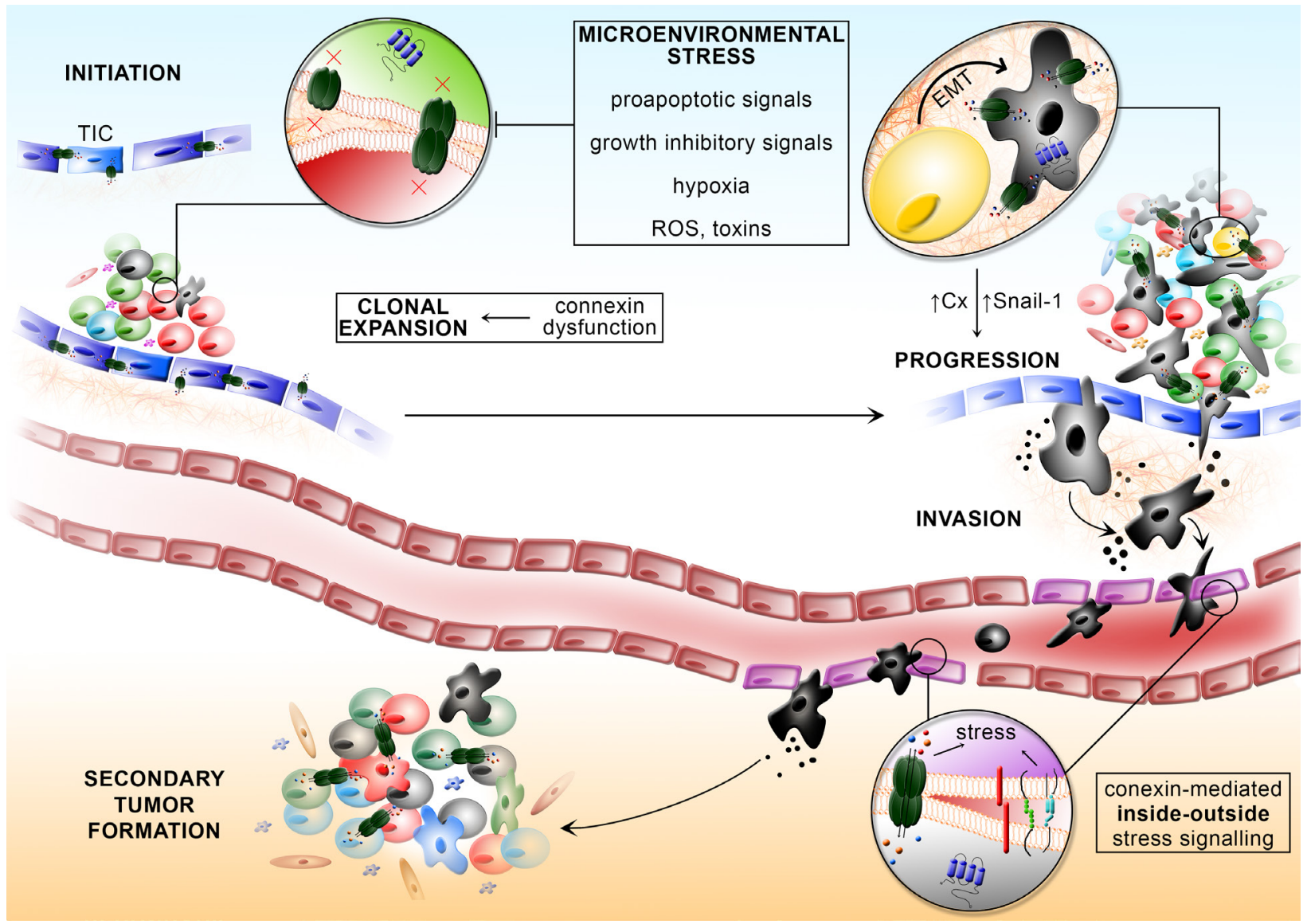

Figure 2. Connexin-dependent stress signaling in cancer promotion and progression.

Connexin deficiency/dysfunction promotes aberrant cancer cell proliferation and differentiation during tumor initiation and promotion. It drives the phenotypic diversity of the cells constituting the primary tumor cell mass and the expansion of invasive cancer cell sub-populations. They are characterized by high motile activity, nanomechanical elasticity, and the expression of connexins (Cx). During tumor progression, connexins expressed by invasive (post-EMT) cells participate in the inside-out stress signaling which facilitates tumor cell diapedesis and metastatic cascade.

bcl2, bax- and caspase-dependent signaling pathways and to the release of ROS from mitochondria (Krysko et al., 2005; Rodriguez-Sinovas et al., 2007). Thus, deficiency of Cx43, $\mathrm{C} \times 32$ and $\mathrm{Cx} 26$ in tumor cells can disturb the apoptosis-related gene expression in a GJIC-independent manner, whereas their re-expression is associated with the re-activation of pro-apoptotic signaling in tumor cells (Huang et al., 2001) (Table 1).

Collectively, the accumulating data show that connexin dysfunctions augment the resistance of connexin-deficient tumor cells to steric tissue constraints and to systemic defense mechanisms (for review see: Vinken et al., 2011; Aasen, 2015). Resistance of tumor cells to contact-phenomena facilitates the expansion of stress- and drug-resistant sub-clones within the primary tumors. Disturbed propagation/amplification of pro-apoptotic signals in connexin-deficient tumor cells cooperates with hyperactive multi-drug resistance (MDR) and autophagy systems, further augmenting tumor cells' resistance to adverse micro environmental factors, i.e. to toxic metabolites, ROS species or chemotherapeutics. The connexin dysfunction in tumor cells can also help them to overcome the pressure from the immune system (Oviedo-Orta \& Evans, 2002). Consequently, tumor cells are more resistant to extreme deviations of the parameters that determine tissue and cellular homeostasis. Together with reprogrammed energy metabolism (i.e. Warburg effect), the dysfunction of connexins facilitates the microevolu- tion adaptation of the cells to the dynamic conditions of the developing tumor. Furthermore, it can increase their predilection to undertake erroneous differentiation programs, which result in the formation of invasive sub-populations (Loewenstein, 1979; Yamasaki et al., 1999; Leithe et al., 2006; Naus \& Laird, 2010; Hanahan \& Weinberg, 2011; Czyz et al., 2012) (Fig. 2).

\section{Connexins, intercellular stress signaling and tumor progression}

Clonal evolution of invasive tumor cells governs tumor malignacy, i.e. its predilection for colonisation of distant organs. Tumor cell invasiveness is determined by their susceptibility to permissive microenvironmental signals, chemotactic motility and nanomechanical elasticity (Wysoczynski et al., 2007; Kumar \& Weaver, 2009; Boiko et al., 2010; Bechyne et al., 2011; Friedl \& Alexander, 2011; Langley \& Fidler, 2011; Visvader, 2011; Fredebohm et al., 2012; Shibata \& Shen, 2013). Although connexins inhibit tumorigenesis at its early stages, relatively high expression of connexins often correlates with the invasive potential of tumor cells (Leithe et al., 2006; Mol et al., 2007; Czyz, 2008; Czyz et al., 2012). Data on the involvement of connexins, connexons and gap junctional channels in the "metastatic cascade" of tumors started to accumulate in 1990s (Brauner et al., 1990; Brauner \& Hülser, 1990). Since then, interrelations between high Cx26, Cx32 and Cx43 levels and an invasive cell pheno- 
type were described in the populations of glioma, lung, prostate, breast cancer and melanoma cells (for review see: Defamie et al., 2014). Nowadays, it is clear that the erroneous up-regulation of connexins is a part of heritable switches that promote invasive behavior of tumour cells during tumor progression. These findings prompted the discussion on the stage-dependent connexin function during tumor promotion and progression, incl. the formation of metastases (Czyz, 2008; Dbouk et al., 2009; Czyz et al., 2012; Defamie et al., 2014). However, they also stimulated discussions on the significance of microenvironmental stress for the formation and expansion of Cx26-, Cx32- and Cx43-positive cell sub-populations within the connexin-negative primary tumors.

Numerous reports show the mechanistic links between the invasive cell behavior and connexin expression in normal and cancer cells (Czyz et al., 2005; Li et al., 2007; Omori et al., 2007; El Saghir et al., 2011; Czyz et al., 2012; Sin et al., 2012; Zucker et al., 2013). Conceivably, these links are related to the GJIC-dependent and GJIC-independent involvement of connexins and connexons in cell adhesion, mechanosensitivity and directed motility (Elias et al., 2007; Cotrina et al., 2008; Cronier et al., 2009). The increased expression of $\mathrm{Cx} 26$ and $\mathrm{Cx} 43$ has been correlated with the increased motility of glioma, glioblastoma, melanoma cells as well as prostate, gastric and breast cancer cells. It also enhances their nanomechanical elasticity, susceptibility to chemotactic and haptotactic cues, and secretion of cytokines and metalloproteinases (Tate et al., 2006; Bechyne et al., 2011; Garcia-Rodriguez et al., 2011; Lamiche et al., 2011; Szpak et al., 2011). This correlation results from interactions of connexins and connexons with a myriad of submembrane protein assemblies within the gap junction proteome (for review see: Dbouk et al., 2009; Mroue et al., 2011). Noteworthy, cells that constitute malignant tumors are predominantly characterized by over-active multi-drug resistance (MDR) systems, dysfunctional pro-apoptotic pathways and reprogrammed energy metabolism. Thus, they are less susceptible to connexin-dependent generation, propagation and amplification of stress signals. Consequently, phenotypic shifts that prompt the "re-expression" of connexins in originally connexin-deficient cells can enhance their malignant behavior without a considerable effect on their welfare.

For instance, $\mathrm{Cx} 43$ increases the invasive potential of prostate cancer cells through direct involvement in epithelial-mesenchymal transition (EMT). EMT is a sequence of phenotypic shifts that augments the invasive potential of cancer cells. These shifts include the acquisition of rear-front cell polarity, plasticity and motility by originally benign epithelioid tumor cells. EMT is induced by numerous extrinsic stimuli and regulated by a plethora of transcriptional regulators, including Snail-1 (Berx et al., 2007; Thiery et al., 2009; Savagner, 2010). We have shown that $\mathrm{Cx} 43$ constitutes a positive feedback loop with Snail-1/Smad2-dependent signaling, which induces EMT in prostate cancer cells (Ryszawy et al., 2014). Its activation leads to the concomitant EMT and Cx43 up-regulation in prostate cancer cells. Because EMT increases the ability of tumor cells to cross tissue barriers, it can help them to avoid/escape stressful conditions. Moreover, EMT was found to correlate with the resistance of tumor cells to the extrinsic stress (for review see: Koumenis, 2014). Further studies are necessary to verify whether $\mathrm{Cx} 43 /$ Snail-1/Cx43 loop may regulate the activity of MDR systems. However, it is clear that connexins can participate in the microevolution of stress-re- sistant tumor cell lineages and in the functional stabilization of the invasive front of tumor (Brabletz, 2012).

The relationships between $\mathrm{Cx} 43$ and the invasive phenotype of tumor cells may also underlie the mechanisms of tumor cell homing in a "comfortable" metastatic niche. Connexins participate in the penetration of natural barriers by invasive tumor cells, thus facilitating their homing in metastatic niches. Connexins and gap junctions apparently confer "inside-out" stress signaling from tumor cells to the stroma that favors tumor cell extravasation. Cx43 is involved in the diapedesis of melanoma, glioblastoma, breast, lung and gastric cancer cells (El Sabban \& Pauli, 1991; El Sabban \& Pauli, 1994; Ito et al., 2000; Zhang et al., 2003a; Pollmann et al., 2005; Naoi et al., 2007; Elzarrad et al., 2008; Tang et al., 2013; Piwowarczyk et al., 2015; Ryszawy et al., 2014). Cx43 function during this process may be attributed to the disturbance of endothelial calcium homeostasis by GJIC-mediated calcium fluxes from tumor to endothelial cells (Lewalle et al., 1998). We have recently demonstrated that prostate cancer cells can also activate the "inside-out" stress signaling axis with endothelial cells in Cx43-dependent, GJIC-independent manner (Piwowarczyk et al., 2015; Piwowarczyk et al., 2017). Other studies showed increased apoptosis of endothelial cells in the proximity of tumor cells, however the involvement of connexin in this process still requires experimental verification. Collectively, multifaceted functions of connexins provide the background for their complex involvement in generation, propagation and detection of stress signals during tumor invasion. They may be responsible for high levels of Cx43, Cx32 and Cx26 in secondary tumors in vivo (Kanczuga-Koda et al., 2006; Kanczuga-Koda et al., 2007; Chao et al., 2011; Stoletov et al., 2013) and for increased drug-resistance of progressed tumors.

\section{SUMMARY AND OUTLOOK}

Gap junctional channels provide a route for metabolic and electrical synchronization of multicellular compartments. As such, they are indispensable in limiting cellular stress resulting from nutritious starvation, hyper- and hypoxia. However, connexins can also serve as universal and sensitive transmitters and sensors of intercellular stress signals. Connexin-dependent stress signaling activates cell death programs that eliminate damaged cells from the organism. It also regulates cellular adaptation to tissue constraints, and preserves tissue functionality through promoting cellular specialization/apoptosis during developmental and regenerative processes. These multiple, context-specific functions situate connexins in the centre of the integrated system that generates, propagates and amplifies stress signals. Further studies on the role of connexins and gap junctions in regulating cell sensitivity to environmental stress signals, in cell adaptation to stressful conditions and in cell death signaling may help to better understand the mechanisms underlying embryogenesis and tissue homeostasis.

In the light of these data, pharmacological modulation of connexin-mediated stress responses presents a potentially attractive strategy in the therapy of numerous chronic diseases. For instance, there are numerous speculations concerning application of the connexin-based gene transfer technology in combination with conventional approaches in a tumor therapy. During cancer development, connexin-dependent stress signaling and cell responses to extrinsic stress signals participate in the selective pressure conferred by different environments, 
which lead to different growth rates of the cell clones within neoplasm. In particular, connexins cooperate with stochastic genetic and epigenetic changes in determining the heterogeneity of primary tumor cells and in the microevolution of invasive cancer cell subsets. Due to the role of connexins in determining tumor cells' sensitivity to stress, the approaches based on the restoration of connexin expression in connexin-deficient tumor cells could help to increase the efficiency of chemotherapeutic approaches in tumor treatment. However, connexins-dependent stress signaling cooperates with dynamically established loops of intercellular communication during tumor progression and metastatic cascade (Marusyk \& Polyak, 2013). Connexins and gap junctions also participate in "inside-out" stress signaling between tumor cells and microenvironment that increases their drug-resistance, and facilitates their expansion and metastasis. Further studies should elucidate the consequences of switching between connexin-positive and connexin-negative cell phenotypes for survival strategies of tumor cells in fluctuating environment. Owing to this pleiotropic involvement of connexins in tumor development, therapeutic regimens based on the modulation of connexin-mediated cellular stress responses should be considered with caution and tailored to individual patients.

\section{Conflicts of interest}

The authors declare no conflict of interest.

\section{Acknowledgement}

The Faculty of Biochemistry, Biophysics and Biotechnology of the Jagiellonian University is a partner of the Leading National Research Center (KNOW) supported by the Ministry of Science and Higher Education.

\section{Funding}

The current authors' research on the topics discussed in this review is supported by the Polish $\mathrm{Na}$ tional Science Centre (grant 2015/17/B/NZ3/01040, 2015/19/D/NZ3/00273 and 2013/09/N/NZ3/00204).

\section{REFERENCES}

Aasen T (2015) Connexins: junctional and non-junctional modulators of proliferation. Cell Tissue Res 360: 685-699. doi: 10.1007/s00441014-2078-3

Abercrombie M (1970) Contact inhibition in tissue culture. In Vitro 6: 128-142. doi: 10.1007/BF02616114

Ai XL, Chi Q, Qiu Y, Li HY, Li DJ, Wang JX, Wang ZY (2017) Gap junction protein connexin43 deregulation contributes to bladder carcinogenesis via targeting MAPK pathway. Mol Cell Biochem 428: 1-10. doi: 10.1103/PhysRevLett.118.112001

Andrysik Z, Prochazkova J, Kabatkova M, Umannova L, Simeckova P, Kohoutek J, Kozubik A, Machala M, Vondracek J (2013) Aryl hydrocarbon receptor-mediated disruption of contact inhibition is associated with connexin43 downregulation and inhibition of gap junctional intercellular communication. Arch Toxicol 87: 491-503. doi: 10.1007/s00204-012-0963-7

Artesi M, Kroonen J, Bredel M, Nguyen-Khac M, Deprez M, Schoysman L, Poulet C, Chakravarti A, Kim H, Scholtens D, Seute T, Rogister B, Bours V, Robe PA (2015) Connexin 30 expression inhibits growth of human malignant gliomas but protects them against radiation therapy. Neuro Oncol 17: 392-406. doi: 10.1093/neuonc/ nou 215

Asamoto M, Hokaiwado N, Murasaki T, Shirai T (2004) Connexin 32 dominant-negative mutant transgenic rats are resistant to hepatic damage by chemicals. Hepatology 40: 205-210. doi: 10.1002/ hep. 20256

Baines CP (2010) The cardiac mitochondrion: nexus of stress. Annu Rev Physiol 72: 61-80. doi: 10.1146/annurev-physiol-021909-135929

Balla P, Maros ME, Barna G, Antal I, Papp G, Sapi Z, Athanasou NA, Benassi MS, Picci P, Krenacs T (2015) Prognostic impact of reduced connexin43 expression and gap junction coupling of neoplastic stromal cells in giant cell tumor of bone. PLoS One 10: e0125316. doi: 10.1371/journal.pone.0125316

Banerjee D, Gakhar G, Madgwick D, Hurt A, Takemoto D, Nguyen TA (2010) A novel role of gap junction connexin46 protein to protect breast tumors from hypoxia. Int J Cancer 127: 839-848. doi: $10.1002 /$ ijc. 25107

Bechyne I, Szpak K, Madeja Z, Czyz J (2011) Functional heterogeneity of non-small lung adenocarcinoma cell sub-populations. Cell Biol Int 36: 99-103. doi: 10.1042/CBI20110151

Benko G, Spajić B, Demirović A, Stimac G, Kru Sbreve Lin B, Tomas D (2011) Prognostic value of connexin43 expression in patients with clinically localized prostate cancer. Prostate Cancer Prostatic Dis 14: 90-95. doi: 10.1038/pcan.2010.51

Berthoud VM, Beyer EC (2009) Oxidative stress, lens gap junctions, and cataracts. Antioxid Redox Signal 11: 339-353. doi: 10.1089/ ars.2008.2119

Berx G, Raspe E, Christofori G, Thiery JP, Sleeman JP (2007) PreEMTing metastasis? Recapitulation of morphogenetic processes in cancer. Clin Exp Metastasis 24: 587-597. doi: 10.1007/s10585-0079114-6

Boiko AD, Razorenova OV, van de RM, Swetter SM, Johnson DL, Ly DP, Butler PD, Yang GP, Joshua B, Kaplan MJ, Longaker MT, Weissman IL (2010) Human melanoma-initiating cells express neural crest nerve growth factor receptor CD271. Nature 466: 133-137. doi: 10.3324/haematol.2009.015065

Brabletz T (2012) EMT and MET in metastasis: where are the cancer stem cells? Cancer Cell 22: 699-701. doi: 10.1016/j.ccr.2012.11.009

Brauner T, Hulser DF (1990) Tumor cell invasion and gap junctional communication. II. Normal and malignant cells confronted in multicell spheroids. Invasion metastasis 10: $31-48$

Brauner T, Schmid A, Hulser DF (1990) Tumor cell invasion and gap junctional communication. I. Normal and malignant cells confronted in monolayer cultures. Invasion Metastasis 10: 18-30

Burt JM, Nelson TK, Simon AM, Fang JS (2008) Connexin 37 profoundly slows cell cycle progression in rat insulinoma cells. Am J Physiol Cell Physiol 295: C1103-C1112. doi: 10.1152/ajpcell.299.2008

Carette D, Gilleron J, Chevallier D, Segretain D, Pointis G (2014) Connexin a check-point component of cell apoptosis in normal and physiopathological conditions. Biochimie 101: 1-9. doi: 10.1016/j.biochi.2013.11.015

Caruso RL, Upham BL, Harris C, Trosko JE (2005) Biphasic lindane-induced oxidation of glutathione and inhibition of gap junctions in myometrial cells. Toxicol Sci 86: 417-426. doi: 10.1093/ toxsci/kfi208

Castor LN (1970) Flattening, movement and control of division of epithelial-like cells. J Cell Physiol 75: 57-64. doi: 10.1002/

jcp.1040750107
Chang WW, Lai CH, Chen MC, Liu CF, Kuan YD, Lin ST, Lee CH (2013) Salmonella enhance chemosensitivity in tumor through connexin 43 upregulation. Int J Cancer 133: 1926-1935. doi: 10.18632/ oncotarget.6258

Chao Y, Wu Q, Acquafondata M, Dhir R, Wells A (2011) Partial Mesenchymal to Epithelial Reverting Transition in Breast and Prostate Cancer Metastases. Cancer Microenviron 5: 19-28. doi: 10.1007/ s12307-011-0085-4

Chipman JK, Mally A, Edwards GO (2003) Disruption of gap junctions in toxicity and carcinogenicity. Toxicol Sci 71: 146-153. doi: $10.1093 /$ toxsci/71.2.146

Choudhary M, Naczki C, Chen W, Barlow KD, Case LD, Metheny-Barlow LJ (2015) Tumor-induced loss of mural Connexin 43 gap junction activity promotes endothelial proliferation. BMC Cancer 15: 427. doi: 10.1186/s12885-015-1420-9

Chovatiya R, Medzhitov R (2014) Stress, inflammation, and defense of homeostasis. Mol Cell 54: 281-288. doi: 10.1016/j.molcel.2014.03.030 Contreras JE, Sanchez HA, Veliz LP, Bukauskas FF, Bennett MV, Saez JC (2004) Role of connexin-based gap junction channels and hemichannels in ischemia-induced cell death in nervous tissue. Brain Res Brain Res Rev 47: 290-303. doi: 10.1016/j.brainresrev.2004.08.002

Cotrina ML, Lin JH, Nedergaard M (2008) Adhesive properties of connexin hemichannels. Glia 56: 1791-1798. doi: 10.1002/glia.20728

Cronier L, Crespin S, Strale PO, Defamie N, Mesnil M (2009) Gap junctions and cancer: new functions for an old story. Antioxid Redox Signal 11: 323-338. doi: 10.1089/ars.2008.2153

Czyz J, Madeja Z, Irmer U, Korohoda W, Hulser DF (2005) Flavonoid apigenin inhibits motility and invasiveness of carcinoma cells in vitro. Int J Cancer 114: 12-18. doi: 10.1002/ijc.20620

Czyz J (2008) The stage-specific function of gap junctions during tumourigenesis. Cell Mol Biol Lett 13: 92-102. doi: 10.2478/s11658007-0039-5

Czyz J, Szpak K, Madeja Z (2012) The role of connexins in prostate cancer promotion and progression. Nat Rev Urol 9: 274-282. doi:10.1038/nrurol.2012.14

Dbouk HA, Mroue RM, El Sabban ME, Talhouk RS (2009) Connexins: a myriad of functions extending beyond assembly of gap junction channels. Cell Commun Signal 7: 4. doi: 10.1186/1478-811X-7-4 
De Vuyst E, Decrock E, Cabooter L, Dubyak GR, Naus CC, Evans WH, Leybaert L (2006) Intracellular calcium changes trigger connexin 32 hemichannel opening. EMBO J 25: 34-44. doi: 10.1038/ sj.emboj. 7600908

Decrock E, Vinken M, Bol M, D’Herde K, Rogiers V, Vandenabeele P, Krysko DV, Bultynck G, Leybaert L (2011) Calcium and connexin-based intercellular communication, a deadly catch? Cell Calcium 50: 310-321. doi: 10.1016/j.ceca.2011.05.007

Defamie N, Chepied A, Mesnil M (2014) Connexins, gap junctions and tissue invasion. FEBS Lett 588: 1331-1338. doi: 10.1016/j.febslet.2014.01.012

Doble BW, Dang X, Ping P, Fandrich RR, Nickel BE, Jin Y, Cattini PA, Kardami E (2004) Phosphorylation of serine 262 in the gap junction protein connexin- 43 regulates DNA synthesis in cellcell contact forming cardiomyocytes. J Cell Sci 117: 507-514. doi: $10.1242 /$ jcs. 00889

Ek-Vitorin JF, Burt JM (2013) Structural basis for the selective permeability of channels made of communicating junction proteins. Biocbim Biophys Acta 1828: 51-68. doi: 10.1016/j.bbamem.2012.02.003

El Sabban ME, Pauli BU (1991) Cytoplasmic dye transfer between metastatic tumor cells and vascular endothelium. J Cell Biol 115: 1375-1382. doi: $10.1083 /$ jcb.115.5.1375

El Sabban ME, Pauli BU (1994) Adhesion-mediated gap junctional communication between lung-metastatic cancer cells and endothelium. Invasion Metastasis 14: 164-176

El Saghir JA, El Habre ET, El Sabban ME, Talhouk RS (2011) Connexins: a junctional crossroad to breast cancer. Int J Dev Biol 55: 773-780. doi: $10.1387 /$ ijdb.113372je

Elias LA, Wang DD, Kriegstein AR (2007) Gap junction adhesion is necessary for radial migration in the neocortex. Nature 448: 901907. doi: $10.1038 /$ nature06063

Elzarrad MK, Haroon A, Willecke K, Dobrowolski R, Gillespie MN, Al Mehdi AB (2008) Connexin-43 upregulation in micrometastases and tumor vasculature and its role in tumor cell attachment to pulmonary endothelium. BMC Med 6: 20. doi: 10.1186/1741-7015-6-20

Evans WH, De Vuyst E, Leybaert L (2006) The gap junction cellular internet: connexin hemichannels enter the signalling limelight. Biochem J 397: 1-14. doi: 10.1042/BJ20060175

Foss B, Tronstad KJ, Bruserud O (2010) Connexin-based signaling in acute myelogenous leukemia (AML). Biocbim Biophys Acta 1798: 1-8. doi: 10.1016/j.bbamem.2009.10.014

Fredebohm J, Boettcher M, Eisen C, Gaida MM, Heller A, Keleg S, Tost J, Greulich-Bode KM, Hotz-Wagenblatt A, Lathrop M, Giese NA, Hoheisel JD (2012) Establishment and characterization of a highly tumorigenic and cancer stem cell enriched pancreatic cancer cell line as a well defined model system. PLoS One 7: e48503. https://doi.org/10.1371/journal.pone.0048503

Friedl P, Alexander S (2011) Cancer invasion and the microenvironment: plasticity and reciprocity. Cell 147: 992-1009. doi: 10.1016/j. cell.2011.11.016

Fujimoto E, Sato H, Negishi E, Ueno K, Nagashima Y, Hagiwara K, Yamasaki H, Yano T (2004) Negative growth control of renal cell carcinoma cell by connexin 32: possible involvement of Her-2. Mol Carcinog 40: 135-142. doi: 10.1002/mc.20025

Fulda S, Gorman AM, Hori O, Samali A (2010) Cellular stress responses: cell survival and cell death. Int J Cell Biol 2010: 214074. doi: $10.1155 / 2010 / 214074$

Garcia-Rodriguez L, Perez-Torras S, Carrio M, Cascante A, Garcia-Ribas I, Mazo A, Fillat C (2011) Connexin-26 is a key factor mediating gemcitabine bystander effect. Mol Cancer Ther 10: 505-517. doi: 10.1158/1535-7163

Gielen PR, Aftab Q, Ma N, Chen VC, Hong X, Lozinsky S, Naus CC, Sin WC (2013) Connexin43 confers Temozolomide resistance in human glioma cells by modulating the mitochondrial apoptosis pathway. Neuropharmacology 75: 539-548. doi: 10.1016/j.neuropharm.2013.05.002

Goldberg GS, Bechberger JF, Tajima Y, Merritt M, Omori Y, Gawinowicz MA, Narayanan R, Tan Y, Sanai Y, Yamasaki H, Naus CC, Tsuda H, Nicholson BJ (2000) Connexin43 suppresses MFG-E8 while inducing contact growth inhibition of glioma cells. Cancer Res 60: 6018-6026

Grek CL, Rhett JM, Bruce JS, Ghatnekar GS, Yeh ES (2016) Connexin 43, breast cancer tumor suppressor: Missed connections? Cancer Lett 374: 117-126. doi: 10.1016/j.canlet.2016.02.008

Hanahan D, Weinberg RA (2011) Hallmarks of cancer: the next generation. Cell 144: 646-674. doi: 10.1016/j.cell.2011.02.013

Hattori Y, Fukushima M, Maitani Y (2007) Non-viral delivery of the connexin 43 gene with histone deacetylase inhibitor to human nasopharyngeal tumor cells enhances gene expression and inhibits in vivo tumor growth. Int J Oncol 30: 1427-1439. doi: 10.3892/ijo.30.6.1427

Hattori Y, Maitani Y (2005) Folate-linked nanoparticle-mediated suicide gene therapy in human prostate cancer and nasopharyngeal cancer with herpes simplex virus thymidine kinase. Cancer Gene Ther 12: 796-809. doi: $10.1038 /$ sj.cot. 7700844

Heckman CA (2009) Contact inhibition revisited. J Cell Physiol 220: 574-575. doi: $10.1002 /$ jcp. 21775
Hirschi KK, Xu CE, Tsukamoto T, Sager R (1996) Gap junction genes Cx26 and Cx43 individually suppress the cancer phenotype of human mammary carcinoma cells and restore differentiation potential. Cell Growth Differ 7: 861-870

Hokaiwado N, Asamoto M, Futakuchi M, Ogawa K, Takahashi S, Shirai $\mathrm{T}$ (2007) Both early and late stages of hepatocarcinogenesis are enhanced in $\mathrm{Cx} 32$ dominant negative mutant transgenic rats with disrupted gap junctional intercellular communication. J Membr Biol 218: 101-106. doi: 10.1007/s00232-007-9053-9

Huang RP, Hossain MZ, Huang R, Gano J, Fan Y, Boynton AL (2001) Connexin 43 (cx43) enhances chemotherapy-induced apoptosis in human glioblastoma cells. Int I Cancer 92: 130-138. doi: 10.1002/1097-0215

Hutnik CM, Pocrnich CE, Liu H, Laird DW, Shao Q (2008) The protective effect of functional connexin 43 channels on a human epithelial cell line exposed to oxidative stress. Invest Ophthalmol Vis Sci 49: 800-806. doi: 10.1167/iovs.07-0717

Ishikawa S, Kuno A, Tanno M, Miki T, Kouzu H, Itoh T, Sato T, Sunaga D, Murase H, Miura T (2012) Role of connexin-43 in protective PI3K-Akt-GSK-3beta signaling in cardiomyocytes. Am J Physiol Heart Circ Physiol 302: H2536-H2544. doi: 10.1152/ ajpheart.00940.2011

Ito A, Katoh F, Kataoka TR, Okada M, Tsubota N, Asada H, Yoshikawa K, Maeda S, Kitamura Y, Yamasaki H, Nojima H (2000) A role for heterologous gap junctions between melanoma and endothelial cells in metastasis. J Clin Invest 105: 1189-1197. doi: 10.1172/JCI8257

Iyyathurai J, Decuypere JP, Leybaert L, D’hondt C, Bultynck G (2016) Connexins: substrates and regulators of autophagy. BMC Cell Biol 17 (Suppl 1): 20. doi: 10.1186/s12860-016-0093-9

Jensen K, Patel A, Klubo-Gwiazdzinski J, Bauer A, Vasko V (2011) Inhibition of gap junction transfer sensitizes thyroid cancer cells to anoikis. Endocr Relat Cancer 18: 613-626. doi: 10.1530/ERC-10-0289

Jayaraman MM, Srisakul DW, Nickel BE, Kardami E (2012) Connexin43 phosphorylation and cytoprotection in the heart. Biochim Biophys Acta 1818: 2009-2013. http://doi.org/10.1016/j.bbamem.2011.06.023

Jin Z, Xu S, Yu H, Yang B, Zhao H, Zhao G (2013) miR-125b inhibits Connexin43 and promotes glioma growth. Cell Mol Neurobiol 33: 1143-1148. doi: $10.1007 / \mathrm{s} 10571-013-9980-1$

Jing Y, Guo S, Zhang X, Sun A, Tao F, Ju H, Qian H (2014) Effects of small interfering RNA interference of connexin 37 on subcutaneous gastric tumours in mice. Mol Med Rep 10: 2955-2960. doi: $10.3892 / \mathrm{mmr} .2014 .2609$

Johnson LN, Koval M (2009) Cross-talk between pulmonary injury, oxidant stress, and gap junctional communication. Antioxid Redox Signal 11: 355-367. doi:10.1089/ars.2008.2183

Kanczuga-Koda L, Sulkowski M, Koda M, Rutkowski R, Sulkowski S (2007) Increased expression of gap junction protein - connexin 32 in lymph node metastases of human ductal breast cancer. Folia Histochem Cytobiol 45 (Suppl 1): S175-S180

Kanczuga-Koda L, Sulkowski S, Lenczewski A, Koda M, Wincewicz A, Baltaziak M, Sulkowska M (2006) Increased expression of connexins 26 and 43 in lymph node metastases of breast cancer. J Clin Pathol 59: 429-433. doi: $10.1136 /$ jcp.2005.029272

Kandouz M, Batist G (2010) Gap junctions and connexins as therapeutic targets in cancer. Expert Opin Ther Targets 14: 681-692. doi: 10.1517/14728222.2010.487866

Kar R, Riquelme MA, Werner S, Jiang JX (2013) Connexin 43 channels protect osteocytes against oxidative stress-induced cell death. $J$ Bone Miner Res 28: 1611-1621. doi: 10.1002/jbmr.1917

Kardami E, Dang X, Iacobas DA, Nickel BE, Jayaraman M, Srisakuldee W, Makazan J, Tanguy S, Spray DC (2007) The role of connexins in controlling cell growth and gene expression. Prog Biophys Mol Biol 94: 245-264. doi: 10.1016/j.pbiomolbio.2007.03.009

Kim JS, Lee WM, Rhee HC, Kim S (2016) Red paprika (Capsicum annuum L.) and its main carotenoids, capsanthin and beta-carotene, prevent hydrogen peroxide-induced inhibition of gap-junction intercellular communication. Chem Biol Interact 254: 146-155. doi: 10.1016/i.cbi.2016.05.004

Knabb MT, Danielsen CA, McShane-Kay K, Mbuy GK, Woodruff RI (2007) Herpes simplex virus-type 2 infectivity and agents that block gap junctional intercellular communication. Virus Res 124: 212-219. doi: $10.1016 /$ j.virusres.2006.11.006

Koffler L, Roshong S, Kyu PI, Cesen-Cummings K, Thompson DC, Dwyer-Nield LD, Rice P, Mamay C, Malkinson AM, Ruch RJ (2000) Growth inhibition in G(1) and altered expression of cyclin D1 and p27(kip-1 )after forced connexin expression in lung and liver carcinoma cells. J Cell Biochem 79: 347-354. doi: 10.1002/1097-4644(20001201) 79:3<347::AID-JCB10>3.0.CO;2-2

Koumenis C, Hammond E, Giaccia A (2014) Tumor Microenvironment and Cellular Stress: Signaling, Metabolism, Imaging, and Therapeutic Targets. Springer Science \& Business Media Press, New York. ISBN 978-14614-5915-6 
Krutovskikh VA, Piccoli C, Yamasaki H (2002) Gap junction intercellular communication propagates cell death in cancerous cells. Oncogene 21: 1989-1999. doi: 10.1038/sj/onc/1205187

Krysko DV, Leybaert L, Vandenabeele P, D'Herde K (2005) Gap junctions and the propagation of cell survival and cell death signals. Apoptosis 10: 459-469. doi: 10.1007/s10495-005-1875-2

Kumar S, Weaver VM (2009) Mechanics, malignancy, and metastasis: the force journey of a tumor cell. Cancer Metastasis Rev 28: 113-127. doi: 10.1007/s10555-008-9173-4

Laird DW (2006) Life cycle of connexins in health and disease. Biochem J 394: 527-543. doi: 10.1042/BJ20051922

Lamiche C, Clarhaut J, Strale PO, Crespin S, Pedretti N, Bernard FX, Naus CC, Chen VC, Foster LJ, Defamie N, Mesnil M, Debiais F, Cronier L (2011) The gap junction protein Cx43 is involved in the bone-targeted metastatic behaviour of human prostate cancer cells. Clin Exp Metastasis 29: 111-122. doi: 10.1007/s10585-011-9434-4

Lampe PD (1994) Analyzing phorbol ester effects on gap junctional communication: a dramatic inhibition of assembly. J Cell Biol 127: 1895-1905. doi: 10.1083/jcb.127.6.1895

Langley RR, Fidler IJ (2011) The seed and soil hypothesis revisited the role of tumor-stroma interactions in metastasis to different organs. Int J Cancer 128: 2527-2535. doi: 10.1002/ijc.26031

Langlois S, Cowan KN, Shao Q, Cowan BJ, Laird DW (2010) The tumor-suppressive function of Connexin43 in keratinocytes is mediated in part via interaction with caveolin-1. Cancer Res 70: 4222-4232. doi: $10.1158 / 0008-5472$

Lee SW, Tomasetto C, Sager R (1991) Positive selection of candidate tumor-suppressor genes by subtractive hybridization. Proc Natl Acad Sci U S A 88: 2825-2829. doi: 10.1073/pnas.88.7.2825

Leithe E, Sirnes S, Omori Y, Rivedal E (2006) Downregulation of gap junctions in cancer cells. Crit Rev Oncog 12: 225-256. doi: 10.1615/ CritRevOncog.v12.i3-4.30

Leithe E (2016) Regulation of connexins by the ubiquitin system: Implications for intercellular communication and cancer. Biochim Biophys Acta 1865: 133-146. doi: 10.1016/j.bbcan.2016.02.001

Lewalle JM, Cataldo D, Bajou K, Lambert CA, Foidart JM (1998) Endothelial cell intracellular $\mathrm{Ca} 2+$ concentration is increased upon breast tumor cell contact and mediates tumor cell transendothelial migration. Clin Exp Metastasis 16: 21-29

Li G, Gao K, Chi Y, Zhang X, Mitsui T, Yao J, Takeda M (2016) Upregulation of connexin43 contributes to PX-12-induced oxidative cell death. Tumour Biol 37: 7535-7546. doi: 10.1007/s13277-0154620-7

Li Q, Omori Y, Nishikawa Y, Yoshioka T, Yamamoto Y, Enomoto K (2007) Cytoplasmic accumulation of connexin 32 protein enhances motility and metastatic ability of human hepatoma cells in vitro and in vivo. Int J Cancer 121: 536-546. doi: 10.1002/ijc.22696

Li X, Xu YB, Wang Q, Lu Y, Zheng Y, Wang YC, Lubbert M, Zhao KW, Chen GQ (2006) Leukemogenic AML1-ETO fusion protein upregulates expression of connexin 43: the role in AML 1-ETOinduced growth arrest in leukemic cells. J Cell Physiol 208: 594-601. doi: 10.1002/jcp.20695

Li X, Pan JH, Song B, Xiong EQ, Chen ZW, Zhou ZS, Su YP (2012) Suppression of CX43 expression by miR-20a in the progression of human prostate cancer. Cancer Biol Ther 13: 890-898. doi: 10.4161/ cbt. 20841

Little JB (2006) Cellular radiation effects and the bystander response. Mutat Res 597: 113-118. doi: 10.1016/j.mrfmmm.2005.12.001

Liu CL, Huang YS, Hosokawa M, Miyashita K, Hu ML (2009) Inhibition of proliferation of a hepatoma cell line by fucoxanthin in relation to cell cycle arrest and enhanced gap junctional intercellular communication. Chem Biol Interact 182: 165-172. doi: 10.1016/j. cbi.2009.08.017

Loch-Caruso R, Galvez MM, Brant K, Chung D (2004) Cell and toxicant specific phosphorylation of conexin43: effects of lindane and TPA on rat myometrial and WB-F344 liver cell gap junctions. Cell Biol Toxicol 20: 147-169. doi: 10.1023/B:CBTO.0000029465.74815.62

Loewenstein WR, Kanno Y (1966) Intercellular communication and the control of tissue growth: lack of communication between cancer cells. Nature 209: 1248-1249. doi: 10.1038/2091248a0

Loewenstein WR, Kanno Y (1967) Intercellular communication and tissue growth. I. Cancerous growth. J Cell Biol 33: 225-234

Loewenstein WR (1979) Junctional intercellular communication and the control of growth. Biochim Biophys Acta 560: 1-65. doi: 10.1016/0304-419X(79)90002-7

Lopez-Otin C, Blasco MA, Partridge L, Serrano M, Kroemer G (2013) The hallmarks of aging. Cell 153: 1194-1217. doi: 10.1016/j. cell.2013.05.039

Lu Z, Qi L, Li GX, Bo XJ, Liu GD, Wang JM (2015) Se-methylselenocysteine suppresses the growth of prostate cancer cell DU145 through connexin 43-induced apoptosis. J Cancer Res Ther 11: 840845. doi: 10.4103/0973-1482.139265

Maeda S, Tsukihara T (2011) Structure of the gap junction channel and its implications for its biological functions. Cell Mol Life Sci 68: 1115-1129. doi: 10.1007/s00018-010-0551-z
Marusyk A, Polyak K (2013) Cancer. Cancer cell phenotypes, in fifty shades of grey. Science 339: 528-529. doi: 10.1126/science.1234415

Meens MJ, Pfenniger A, Kwak BR, Delmar M (2013) Regulation of cardiovascular connexins by mechanical forces and junctions. Cardiovasc Res 99: 304-314. doi: $10.1093 / \mathrm{cvr} / \mathrm{cvt} 095$

Mehta PP, Perez-Stable C, Nadji M, Mian M, Asotra K, Roos BA (1999) Suppression of human prostate cancer cell growth by forced expression of connexin genes. Dev Genet 24: 91-110. doi: 10.1002/ (SICI)1520-6408(1999)24:1/2<91::AID-DVG10>3.0.CO;2-\#

Mol AJ, Geldof AA, Meijer GA, van der Poel HG, van Moorselaar RJ (2007) New experimental markers for early detection of high-risk prostate cancer: role of cell-cell adhesion and cell migration. J Cancer Res Clin Oncol 133: 687-695. doi: 10.1007/s00432-007-0235-8

Momiyama M, Omori Y, Ishizaki Y, Nishikawa Y, Tokairin T, Ogawa J, Enomoto K (2003) Connexin26-mediated gap junctional communication reverses the malignant phenotype of MCF-7 breast cancer cells. Cancer Sci 94: 501-507. doi: 10.1111/j.1349-7006.2003. tb01473.x

Mroue RM, El Sabban ME, Talhouk RS (2011) Connexins and the gap in context. Integr Biol (Camb) 3: 255-266. doi: 10.1039/C0IB00158A

Naiki-Ito A, Asamoto M, Naiki T, Ogawa K, Takahashi S, Sato S, Shirai T (2010) Gap junction dysfunction reduces acetaminophen hepatotoxicity with impact on apoptotic signaling and connexin 43 protein induction in rat. Toxicol Pathol 38: 280-286. doi: $10.1177 / 0192623309357951$

Nakagawa S, Maeda S, Tsukihara T (2010) Structural and functional studies of gap junction channels. Curr Opin Struct Biol 20: 423-430. doi: 10.1016/j.sbi.2010.05.003

Naoi Y, Miyoshi Y, Taguchi T, Kim SJ, Arai T, Tamaki Y, Noguchi $\mathrm{S}$ (2007) Connexin26 expression is associated with lymphatic vessel invasion and poor prognosis in human breast cancer. Breast Cancer Res Treat 106: 11-17. doi: 10.1007/s10549-006-9465-8

Naus CC, Laird DW (2010) Implications and challenges of connexin connections to cancer. Nat Rev Cancer 10: 435-441. doi: 10.1038/ nrc 2841

Nelson CM, Bissell MJ (2006) Of extracellular matrix, scaffolds, and signaling: tissue architecture regulates development, homeostasis, and cancer. Annu Rev Cell Dev Biol 22: 287-309. doi: 10.1146/annurev.cellbio.22.010305.104315

Nielsen MS, Nygaard AL, Sorgen PL, Verma V, Delmar M, Holstein-Rathlou NH (2012) Gap junctions. Compr Physiol 2: 1981-2035. doi: $10.1002 /$ cphy.c110051

Omori Y, Li Q, Nishikawa Y, Yoshioka T, Yoshida M, Nishimura T, Enomoto K (2007) Pathological significance of intracytoplasmic connexin proteins: implication in tumor progression. J Membr Biol 218: 73-77. doi: $10.1007 / \mathrm{s} 00232-007-9048-6$

Orellana JA, Sanchez HA, Schalper KA, Figueroa V, Saez JC (2012) Regulation of intercellular calcium signaling through calcium interactions with connexin-based channels. Adv Exp Med Biol 740: 777794. doi: 10.1007/978-94-007-2888-2_34

Orrenius S, Zhivotovsky B, Nicotera P (2003) Regulation of cell death: the calcium-apoptosis link. Nat Rev Mol Cell Biol 4: 552-565. doi: $10.1038 / \mathrm{nrm} 1150$

Oshima A (2014) Structure and closure of connexin gap junction channels. FEBS Lett 588: 1230-1237. doi: 10.1016/j.febslet.2014.01.042

Oviedo-Orta E, Evans WH (2002) Gap junctions and connexins: potential contributors to the immunological synapse. I Lenkoc Biol 72: 636-642

Piwowarczyk K, Paw M, Ryszawy D, Rutkowska-Zapała M, Madeja Z, Siedlar M, Czyz J (2017) Connexin43 high prostate cancer cells induce endothelial connexin43 up-regulation through the activation of intercellular ERK1/2-dependent signaling axis. Eur J Cell Biol. doi: 10.1016/j.ejcb.2017.03.012

Piwowarczyk K, Wybieralska E, Baran J, Borowczyk J, Rybak P, Kosinska M, Wlodarczyk AJ, Michalik M, Siedlar M, Madeja Z, Dobrucki J, Reiss K, Czyz J (2015) Fenofibrate enhances barrier function of endothelial continuum within the metastatic niche of prostate cancer cells. Expert Opin Ther Targets 19: 163-176. doi: 10.1517/14728222.2014.981153

Plotkin LI, Stains JP (2015) Connexins and pannexins in the skeleton: gap junctions, hemichannels and more. Cell Mol Life Sci 72: 28532867. doi: 10.1007/s00018-015-1963-6

Pogoda K, Kameritsch P, Retamal MA, Vega JL (2016) Regulation of gap junction channels and hemichannels by phosphorylation and redox changes: a revision. BMC Cell Biol 17 (Suppl 1): 11. doi: 10.1186/s12860-016-0099-3

Pollmann MA, Shao Q, Laird DW, Sandig M (2005) Connexin 43 mediated gap junctional communication enhances breast tumor cell diapedesis in culture. Breast Cancer Res 7: R522-R534. doi: 10.1186/ bcr1042

Puliafito A, Hufnagel L, Neveu P, Streichan S, Sigal A, Fygenson DK, Shraiman BI (2012) Collective and single cell behavior in epithelial contact inhibition. Proc Natl Acad Sci U S A 109: 739-744. doi: 10.1073 /pnas.1007809109

Qin H, Shao Q, Thomas T, Kalra J, Alaoui-Jamali MA, Laird DW (2003) Connexin26 regulates the expression of angiogenesis-related 
genes in human breast tumor cells by both GJIC-dependent and -independent mechanisms. Cell Commun Adhes 10: 387-393

Quintanilla RA, Orellana JA, von Bernhardi R (2012) Understanding risk factors for Alzheimer's disease: interplay of neuroinflammation, connexin-based communication and oxidative stress. Arch Med Res 43: 632-644. doi: 10.1016/j.arcmed.2012.10.016

Ramachandran S, Xie LH, John SA, Subramaniam S, Lal R (2007) A novel role for connexin hemichannel in oxidative stress and smoking-induced cell injury. PLoS One 2: e712. doi: 10.1371/journal. pone.0000712

Ren P, Mehta PP, Ruch RJ (1998) Inhibition of gap junctional intercellular communication by tumor promoters in connexin43 and connexin32-expressing liver cells: cell specificity and role of protein kinase C. Carcinogenesis 19: 169-175. doi: https://doi.org/10.1093/ carcin/19.1.169

Retamal MA, Reyes EP, Garcia IE, Pinto B, Martinez AD, Gonzalez C (2015) Diseases associated with leaky hemichannels. Front Cell Neurosci 9: 267. doi: 10.3389/fncel.2015.00267

Rodriguez-Sinovas A, Cabestrero A, Lopez D, Torre I, Morente M, Abellan A, Miro E, Ruiz-Meana M, Garcia-Dorado D (2007) The modulatory effects of connexin 43 on cell death/survival beyond cell coupling. Prog Biophys Mol Biol 94: 219-232. doi: 10.1016/j.pbiomolbio.2007.03.003

Ryszawy D, Sarna M, Rak M, Szpak K, Kedracka-Krok S, Michalik M, Siedlar M, Zuba-Surma E, Burda K, Korohoda W, Madeja Z, Czyz $\mathrm{J}$ (2014) Functional links between Snail-1 and Cx43 account for the recruitment of $\mathrm{Cx} 43$-positive cells into the invasive front of prostate cancer. Carcinogenesis 35: 1920-1930. doi: 10.1093/carcin/bgu033

Saez JC, Retamal MA, Basilio D, Bukauskas FF, Bennett MV (2005) Connexin-based gap junction hemichannels: gating mechanisms. Biochim Biophys Acta 1711: 215-224. doi: 10.1016/j.bbamem.2005.01.014

Saez JC, Schalper KA, Retamal MA, Orellana JA, Shoji KF, Bennett MV (2010) Cell membrane permeabilization via connexin hemichannels in living and dying cells. Exp Cell Res 316: 2377-2389. doi: 10.1016/j.yexcr.2010.05.026

Samali A, Fulda S, Gorman AM, Hori O, Srinivasula SM (2010) Cell stress and cell death. Int J Cell Biol: Article ID 245803. doi: $10.1155 / 2010 / 245803$

Sato H, Fukumoto K, Hada S, Hagiwara H, Fujimoto E, Negishi E, Ueno K, Yano T (2007a) Enhancing effect of connexin 32 gene on vinorelbine-induced cytotoxicity in A549 lung adenocarcinoma cells. Cancer Chemother Pharmacol 60: 449-457. doi: 10.1007/s00280006-0406-3

Sato H, Senba H, Virgona N, Fukumoto K, Ishida T, Hagiwara H, Negishi E, Ueno K, Yamasaki H, Yano T (2007b) Connexin 32 potentiates vinblastine-induced cytotoxicity in renal cell carcinoma cells. Mol Carcinog 46: 215-224. doi: 10.1002/mc.20267

Sato H, Iwata H, Takano Y, Yamada R, Okuzawa H, Nagashima Y, Yamaura K, Ueno K, Yano T (2009) Enhanced effect of connexin 43 on cisplatin-induced cytotoxicity in mesothelioma cells. J Pharmacol Sci 110: 466-475. doi.org/10.1254/jphs.08327FP

Savagner P (2010) The epithelial-mesenchymal transition (EMT) phenomenon. Ann Oncol 21 (Suppl 7): vii89-vii92. doi: 10.1093/annonc/mdq292

Schalper KA, Riquelme MA, Branes MC, Martinez AD, Vega JL, Berthoud VM, Bennett MV, Saez JC (2012) Modulation of gap junction channels and hemichannels by growth factors. Mol Biosyst 8: 685-698. doi: 10.1039/c1mb05294b

Shibata M, Shen MM (2013) The roots of cancer: Stem cells and the basis for tumor heterogeneity. Bioessays 35: 253-260. doi: 10.1002/ bies.201200101

Shishido SN, Nguyen TA (2016) Induction of apoptosis by PQ1, a gap junction enhancer that upregulates connexin 43 and activates the MAPK signaling pathway in mammary carcinoma cells. Int J Mol Sci 17: 178. doi: 10.3390/ijms17020178

Sin WC, Crespin S, Mesnil M (2012) Opposing roles of connexin43 in glioma progression. Biochim Biophys Acta 1818: 2058-2067. doi: 10.1016/j.bbamem.2011.10.022

Sinyuk M, Alvarado AG, Nesmiyanov P, Shaw J, Mulkearns-Hubert EE, Eurich JT, Hale JS, Bogdanova A, Hitomi M, Maciejewski J, Huang AY, Saunthararajah Y, Lathia JD (2015) Cx25 contributes to leukemia cell communication and chemosensitivity. Oncotarget 6: 31508-31521. doi: 10.18632/oncotarget.5226

Sirnes S, Lind GE, Bruun J, Fykerud TA, Mesnil M, Lothe RA, Rivedal E, Kolberg M, Leithe E (2015) Connexins in colorectal cancer pathogenesis. Int J Cancer 137: 1-11. doi: 10.1002/ijc.28911

Sohl G, Willecke K (2004) Gap junctions and the connexin protein family. Cardiovasc Res 62: 228-232. doi: 10.1016/j.cardiores.2003.11.013

Sovari AA (2016) Cellular and Molecular Mechanisms of Arrhythmia by Oxidative Stress. Cardiol Res Pract. Article ID 9656078. doi: 10.1155/2016/9656078

Sroka J, Czyz J, Wojewoda M, Madeja Z (2008) The inhibitory effect of diphenyltin on gap junctional intercellular communication in HEK-293 cells is reduced by thioredoxin reductase 1 . Toxicol Lett 183: 45-51. doi: 10.1016/j.toxlet.2008.09.012
Stoletov K, Strnadel J, Zardouzian E, Momiyama M, Park FD, Kelber JA, Pizzo DP, Hoffman R, VandenBerg SR, Klemke RL (2013) Role of connexins in metastatic breast cancer and melanoma brain colonization. J Cell Sci 126: 904-913. doi: 10.1242/jcs.112748

Su V, Lau AF (2014) Connexins: mechanisms regulating protein levels and intercellular communication. FEBS Lett 588: 1212-1220. doi: 10.1016/j.febslet.2014.01.013

Su YA, Bittner ML, Chen Y, Tao L, Jiang Y, Zhang Y, Stephan DA, Trent JM (2000) Identification of tumor-suppressor genes using human melanoma cell lines UACC903, UACC903(+6), and SRS3 by comparison of expression profiles. Mol Carcinog 28: 119-127. doi: 10.1002/1098-2744(200006)28:2<119::AID-MC8>3.0.CO;2-N

Sun P, Liu Y, Ying H, Li S (2012a) Action of db-cAMP on the bystander effect and chemosensitivity through connexin 43 and Bcl-2-mediated pathways in medulloblastoma cells. Oncol Rep 28: 969-976. doi: 10.3892/or.2012.1900

Sun Y, Zhao X, Yao Y, Qi X, Yuan Y, Hu Y (2012b) Connexin 43 interacts with Bax to regulate apoptosis of pancreatic cancer through a gap junction-independent pathway. Int J Oncol 41: 941-948. doi: 10.3892/ijo.2012.1524

Szpak K, Wybieralska E, Niedzialkowska E, Rak M, Bechyne I, Michalik M, Madeja Z, Czyz J (2011) DU-145 prostate carcinoma cells that selectively transmigrate narrow obstacles express elevated levels of CX43. Cell Mol Biol Lett 16: 625. doi:10.2478/s11658-011-0027-7

Tanaka M, Grossman HB (2001) Connexin 26 gene therapy of human bladder cancer: induction of growth suppression, apoptosis, and synergy with Cisplatin. Hum Gene Ther 12: 2225-2236. doi: $10.1089 / 10430340152710568$

Tanaka M, Grossman HB (2004) Connexin 26 induces growth suppression, apoptosis and increased efficacy of doxorubicin in prostate cancer cells. Oncol Rep 11: 537-541. doi: 10.3892/or.11.2.537

Tang B, Peng ZH, Yu PW, Yu G, Qian F, Zeng DZ, Zhao YL, Shi Y, Hao YX, Luo HX (2013) Aberrant expression of Cx43 is associated with the peritoneal metastasis of gastric cancer and Cx43mediated gap junction enhances gastric cancer cell diapedesis from peritoneal mesothelium. PLoS One 8: e74527. doi: 10.1371/journal. pone. 0074527

Tate AW, Lung T, Radhakrishnan A, Lim SD, Lin X, Edlund M (2006) Changes in gap junctional connexin isoforms during prostate cancer progression. Prostate 66: 19-31. doi: 10.1002/pros.20317

Teleki I, Szasz AM, Maros ME, Gyorffy B, Kulka J, Meggyeshazi N, Kiszner G, Balla P, Samu A, Krenacs T (2014) Correlations of differentially expressed gap junction connexins Cx26, Cx30, Cx32, Cx43 and Cx46 with breast cancer progression and prognosis: PLoS One 9: e112541. doi: 10.1371/journal.pone.0112541

Thiery JP, Acloque H, Huang RY, Nieto MA (2009) Epithelial-mesenchymal transitions in development and disease. Cell 139: 871-890. doi: 10.1016/j.cell.2009.11.007

Tinkle CL, Pasolli HA, Stokes N, Fuchs E (2008) New insights into cadherin function in epidermal sheet formation and maintenance of tissue integrity. Proc Natl Acad Sci U S A 105: 15405-15410. doi: 10.1073 /pnas.0807374105

Tittarelli A, Guerrero I, Tempio F, Gleisner MA, Avalos I, Sabanegh S, Ortiz C, Michea L, Lopez MN, Mendoza-Naranjo A, Salazar-Onfray F (2015) Overexpression of connexin 43 reduces melanoma proliferative and metastatic capacity. Br J Cancer 113: 259-267. doi: 10.1038/bjc. 2015.162

Tsujino T, Nagata T, Katoh F, Yamasaki H (2007) Inhibition of Balb/c 3T3 cell transformation by synthetic acyclic retinoid NIK-333; possible involvement of enhanced gap junctional intercellular communication. Cancer Detect Prev 31: 332-338. doi: 10.1016/j.cdp.2007.06.001

VanSlyke JK, Musil LS (2005) Cytosolic stress reduces degradation of connexin43 internalized from the cell surface and enhances gap junction formation and function. Mol Biol Cell 16: 5247-5257. doi: 10.1091/mbc.E05-05-0415

Vanslyke JK, Naus CC, Musil LS (2009) Conformational maturation and post-ER multisubunit assembly of gap junction proteins. Mol Biol Cell 20: 2451-2463. doi: 10.1091/mbc.E09-01-0062

Vinken M, Decrock E, De Vuyst E, Ponsaerts R, D'hondt C, Bultynck G, Ceelen L, Vanhaecke T, Leybaert L, Rogiers V (2011) Connexins: sensors and regulators of cell cycling. Biochim Biophys Acta 1815: 13-25. doi: 10.1016/j.bbcan.2010.08.004

Vinken M, Decrock E, Leybaert L, Bultynck G, Himpens B, Vanhaecke T, Rogiers V (2012) Non-channel functions of connexins in cell growth and cell death. Biochim Biophys Acta 1818: 2002-2008. doi. org/10.1016/j.bbamem.2011.06.011

Visvader JE (2011) Cells of origin in cancer. Nature 469: 314-322. doi: 10.1038 / nature 09781

Wang M, Berthoud VM, Beyer EC (2007) Connexin43 increases the sensitivity of prostate cancer cells to TNFalpha-induced apoptosis. $J$ Cell Sci 120: 320-329. doi: 10.1242/jcs.03343

Wong P, Tan T, Chan C, Laxton V, Chan YW, Liu T, Wong WT, Tse $G$ (2016) The Role of Connexins in Wound Healing and Repair: Novel Therapeutic Approaches. Front Physiol 7: 596. doi: 10.3389/ fphys.2016.00596 
Wong P, Laxton V, Srivastava S, Chan YW, Tse G (2017) The role of gap junctions in inflammatory and neoplastic disorders (Review). Int J Mol Med 39: 498-506. doi: 10.3892/ijmm.2017.2859

Wu L, Zhou WB, Shen F, Liu W, Wu HW, Zhou SJ, Li SW (2016) Connexin32mediated antitumor effects of suicide gene therapy against hepatocellular carcinoma: In vitro and in vivo anticancer activity. Mol Med Rep 13: 3213-3219. doi: 10.3892/mmr.2016.4895

Wysoczynski M, Miekus K, Jankowski K, Wanzeck J, Bertolone S, Janowska-Wieczorek A, Ratajczak J, Ratajczak MZ (2007) Leukemia inhibitory factor: a newly identified metastatic factor in rhabdomyosarcomas. Cancer Res 67: 2131-2140. doi: 10.1158/0008-5472

Yamasaki H, Krutovskikh V, Mesnil M, Tanaka T, Zaidan-Dagli ML, Omori Y (1999) Role of connexin (gap junction) genes in cell growth control and carcinogenesis. $C \stackrel{R}{R}$ Acad Sci III 322: 151-159. doi.org/10.1016/S0764-4469(99)80038-9
Zhang W, DeMattia JA, Song H, Couldwell WT (2003a) Communication between malignant glioma cells and vascular endothelial cells through gap junctions. J Neurosurg 98: 846-853. doi: 10.3171/ jns.2003.98.4.0846

Zhang YW, Kaneda M, Morita I (2003b) The gap junction-independent tumor-suppressing effect of connexin 43. J Biol Chem 278: 44852-44856. doi: 10.1074/jbc.M305072200

Zhang YW, Nakayama K, Nakavama K, Morita I (2003c) A novel route for connexin 43 to inhibit cell proliferation: negative regulation of S-phase kinase-associated protein (Skp 2). Cancer Res 63: 1623-1630

Zucker SN, Bancroft TA, Place DE, Des SB, Bagati A, Berezney R (2013) A dominant negative Cx43 mutant differentially affects tumorigenic and invasive properties in human metastatic melanoma cells. J Cell Physiol 228: 853-859. doi: 10.1002/jcp.24235 